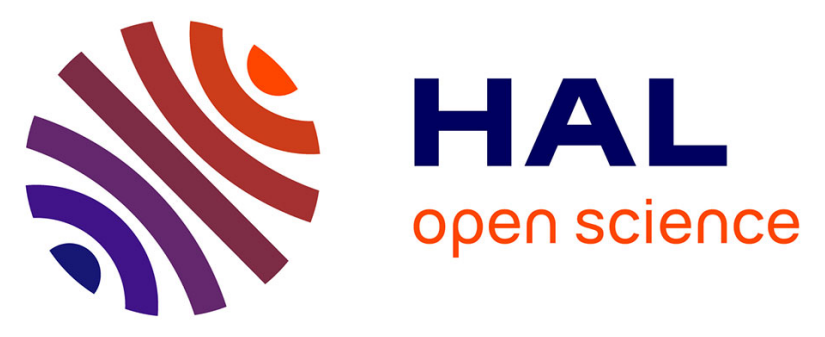

\title{
The Gediz supradetachment system (SW Turkey): magmatism, tectonics and sedimentation during crustal extension
}

\author{
Riccardo Asti, Claudio Faccenna, Federico Rossetti, Marco Malusà, Elsa \\ Gliozzi, Costanza Faranda, Fabrizio Lirer, Domenico Cosentino
}

\section{To cite this version:}

Riccardo Asti, Claudio Faccenna, Federico Rossetti, Marco Malusà, Elsa Gliozzi, et al.. The Gediz supradetachment system (SW Turkey): magmatism, tectonics and sedimentation during crustal extension. Tectonics, 2019, 38 (4), pp.1414-1440. 10.1029/2018TC005181 . insu-02078585

\section{HAL Id: insu-02078585 \\ https://hal-insu.archives-ouvertes.fr/insu-02078585}

Submitted on 15 May 2019

HAL is a multi-disciplinary open access archive for the deposit and dissemination of scientific research documents, whether they are published or not. The documents may come from teaching and research institutions in France or abroad, or from public or private research centers.
L'archive ouverte pluridisciplinaire HAL, est destinée au dépôt et à la diffusion de documents scientifiques de niveau recherche, publiés ou non, émanant des établissements d'enseignement et de recherche français ou étrangers, des laboratoires publics ou privés. 


\section{Tectonics}

\section{RESEARCH ARTICLE 10.1029/2018TC005181}

\section{Special Section:}

Geodynamics, Crustal and Lithospheric Tectonics, and active deformation in the Mediterranean Regions (A tribute to Prof. Renato

Funiciello)

Key Points:

- The spatiotemporal ductile-to-brittle evolution of the Gediz detachment controls the tectonostratigraphic evolution of the Gediz Graben

- An upper Tortonian marine transgression is recorded in the sedimentary fill of the Gediz Graben

- Basins developed in the hanging wall of detachment faults may eventually end up in tectonic contact with the mylonitic footwal

Supporting Information:

- Supporting Information S1

Correspondence to:

R. Asti,

riccardo.asti@univ-rennes1.fr

Citation:

Asti, R., Faccenna, C., Rossetti, F., Malusà, M. G., Gliozzi, E., Faranda, C. et al (2019). The Gediz

supradetachment system (SW Turkey): Magmatism, tectonics, and sedimentation during crustal extension. Tectonics, 38, 1414-1440. https://doi.org/10.1029/ 2018TC005181

Received 10 JUN 2018 Accepted 6 MAR 2019 Accepted article online 19 MAR2019 Published online 17 APR 2019

\section{The Gediz Supradetachment System (SW Turkey): Magmatism, Tectonics, and Sedimentation During Crustal Extension}

\author{
Riccardo Asti ${ }^{1,2}$ (D), Claudio Faccenna ${ }^{2,3}$ (D), Federico Rossetti ${ }^{2}$ (D), Marco G. Malusà ${ }^{4}$ (D), \\ Elsa Gliozzi ${ }^{2}$ (D) Costanza Faranda ${ }^{2}$, Fabrizio Lirer ${ }^{5}$, and Domenico Cosentino ${ }^{2}$ (iD \\ ${ }^{1}$ Univ Rennes, CNRS, Géosciences Rennes-UMR 6118, Rennes, France, ${ }^{2}$ Department of Sciences, Università degli Studi \\ Roma Tre, Rome, Italy, ${ }^{3}$ Jackson School of Geoscience, University of Texas, Austin, USA, ${ }^{4}$ Department of Earth and \\ Environmental Sciences, University of Milano-Bicocca, Milan, Italy, ${ }^{5}$ Istituto di Scienze Marine (ISMAR)-CNR, Naples, Italy
}

\begin{abstract}
Unraveling the evolution of supradetachment basins developed in the hanging wall of low-angle detachment faults may be an invaluable tool in reconstructing the tectonic evolution of highly extended terrains. These basins may record major regional tectonic events related to the exhumation of metamorphic core complexes, and the reconstruction of their evolution helps to quantify the amount of extension accommodated by such processes. Here we present stratigraphic and structural field evidence and micropaleontological constraints to the Neogene-to-Quaternary evolution of the supradetachment Gediz Graben that developed on top of the exhuming Central Menderes Massif (SW Turkey). This basin displays three different structural styles during its evolution: (i) it initiated as a ramp basin following the activation of the Gediz Detachment in the Middle Miocene, (ii) evolved as a half graben during the late Miocene following the activation of high-angle brittle faults at its southern margin, and (iii) reached its final symmetric graben configuration in Late Pliocene (?)-Quaternary times following the activation of its northern margin. New micropaleontological data document a short-lived upper Tortonian marine episode in the basin, and major along-strike variations in exhumation are documented on its southern margin. Our reconstruction shows how sedimentary basins originally formed in the hanging wall of detachment faults may eventually end up in tectonic contact with the mylonitic footwall. Finally, we highlight the importance of magmatism in localizing the deformation in highly extended terrains and in controlling the evolution of supradetachment systems.
\end{abstract}

\section{Introduction}

Supradetachment basins are subsiding regions developed in the hanging wall of highly extended terranes (metamorphic core complexes) exhumed in the footwall of low-angle ductile-to-brittle shear zones, also referred to as detachment faults (e.g., Crittenden et al., 1980; Davis et al., 2004; Lister et al., 1984; Wernicke, 1985; Whitney et al., 2013). After early attempts to define a general model for the formation of supradetachment basins (Friedmann \& Burbank, 1995), several other examples have been studied and characterized all over the world: in the Basin and Range province of the western USA (e.g., Davis \& Friedmann, 2005; Fillmore \& Walker, 1996; Janecke et al., 1999; Snyder \& Hodges, 2000), in the British Columbia (e.g., McClaughry \& Gaylord, 2005), in the Aegean region (e.g., Van Hinsbergen \& Meulenkamp, 2006; Zachariasse et al., 2011; Bargnesi et al., 2013), in the Norwegian Caledonides (e.g., Osmundsen \& Andersen, 2001; Séranne \& Séguret, 1987; Vetti \& Fossen, 2012), and in Chinese Inner Mongolia (e.g., Ritts et al., 2010; Wang et al., 2004). These studies have documented that the spatiotemporal tectonosedimentary evolution is linked to the activity of the detachment faults, as attested by the source-to-sink relationships between the exhumed footwall of the detachment and the basin fill and by concordant ages between cooling/exhumation of the footwall and sedimentation in the basin (e.g., Asti et al., 2018; Bargnesi et al., 2013; Fillmore et al., 1994; Friedmann \& Burbank, 1995; Fillmore \& Walker, 1996; Öner \& Dilek, 2011; van Hinsbergen \& Meulenkamp, 2006; Vetti \& Fossen, 2012). In general, two main types of supradetachment basins may form in the hanging wall of detachment faults (e.g., Fillmore et al., 1994; Vetti \& Fossen, 2012): (i) basins forming as half-grabens at the breakaway of the detachment, with sediments in tectonic contact with mylonitic rocks of the detachment (breakaway basins, hereafter), and (ii) basins forming on the hanging wall of the detachment, far away from the breakaway, developing as sag basins reflecting the 
flat-ramp geometry of the detachment at depth, with sediments unconformably overlying their basement, also referred to as ramp basins. This second category may also evolve in half- and/or full-grabens after the breakup in the hanging wall of the detachment by brittle normal faulting (Fillmore, 1993). Unraveling the evolution of supradetachment basins may then represent a key tool in understanding the evolution of highly extended terrains, yielding important insights into the amount and rates of extension and exhumation.

Western Turkey is located at the eastern termination of the Aegean Extensional Province and is one of the best examples of active continental extension. Between the latest Paleogene and the Neogene, N-S extension led to extreme crustal attenuation, magmatism, and exhumation of the Menderes metamorphic core complex (MMCC, e.g., Hetzel et al., 1995; Gessner et al., 2013, 2001; Ring et al., 2003; Ring \& Collins, 2005; Thomson \& Ring, 2006; Rossetti et al., 2017). Exhumation of the MMCC was accompanied by the formation of a series of Neogene-Quaternary supradetachment basins, oriented both parallel and perpendicular to the N-S trending ductile-to-brittle stretching direction (e.g., Ersoy et al., 2011; Şengör, 1987, and references therein). Among these basins, the Gediz Graben developed in the hanging wall of the ductile-to-brittle north dipping Gediz Detachment (e.g., Cohen et al., 1995; Emre, 1996; Koçyiğit et al., 1999; Seyitoğlu et al., 2002; Purvis \& Robertson, 2005a; Çiftçi \& Bozkurt, 2009a; Öner \& Dilek, 2011) and displays all of the characteristics that are typical of a supradetachment basin. Although many studies have addressed the tectonosedimentary evolution of this basin, there are still some major issues to be solved. In particular, the sedimentary history of the graben has very poor age constraints and its structural evolution is also debated. General agreement exists in the recognition of two distinct deformation styles related to the Neogene extensional phase: an earlier one involving low-angle ductile-to-brittle detachment faulting and a later one involving high-angle brittle faulting (e.g., Bozkurt \& Oberhänsli, 2001, and references therein). The relationship between these two different styles of deformation is still debated, and general agreement is also lacking regarding whether the two extensional phases were continuous (e.g., Glodny \& Hetzel, 2007; Seyitoğlu et al., 2000) or separated in time (possibly with a compressional phase in between; e.g., Koçyiğit et al., 1999; Yılmaz et al., 2000; Purvis \& Robertson, 2004, 2005a; Çiftçi \& Bozkurt, 2009a; Öner \& Dilek, 2011). Moreover, recent detrital apatite fission track studies showed that the exhumation pattern along the southern margin of the basin, where the Gediz Detachment is locally exposed, is not homogeneous (Asti et al., 2018), suggesting possible feedbacks between magma emplacement in the crust and the subsidence/erosion history of the Gediz Graben.

In this study, we use the Gediz Graben as a case study to show how the geometric and tectonic relationships proposed to be diagnostic for the different kinds of supradetachment basins may occur together in a single basin. Based on structural and stratigraphic field evidence and on new paleontological constraints from the Neogene-to-Quaternary sedimentary basin fill, we propose an original tectonostratigraphic evolutionary model. This model aims to explain the development of the Gediz Graben as a ramp basin in the hanging wall of the active Gediz Detachment, which was subsequently affected by brittle faulting and where synextensional deposits were eventually juxtaposed with the exhumed mylonitic rocks of the detachment. Implications of these results are discussed at the regional scale, highlighting the importance of magmatism in localizing the deformation in highly extended terrains and in controlling the evolution of supradetachment systems, in general.

\section{Geological Setting}

The Menderes Massif of Western Turkey (Figure 1) is an outstanding example of metamorphic core complex exhumed during the Cenozoic (Şengör \& Yilmaz, 1981; Sengör et al., 1984; Bozkurt \& Park, 1994; Gessner et al., 2001; Isik \& Tekeli, 2001; Ring et al., 2003; Seyitoğlu et al., 2004; Van Hinsbergen et al., 2010; Rossetti et al., 2017). It is exposed along the southwestern Anatolian portion of the Mediterranean-Alpine belt, which underwent Cenozoic orogenic contraction followed by postorogenic extension, both related to the dynamics and evolution of the Aegean subduction (e.g., Jolivet \& Brun, 2010; Şengör, 1987; Sengör et al., 1984). This portion of the chain is built up of continental fragments of African affinity accreted along the southern margin of Laurasia and separated by major suture zones (Sengör et al., 1984). The Menderes Massif is located in the southernmost of these continental blocks, namely, the Tauride-Anatolide Platform, and is separated from the Sakarya zone to the North by the Izmir-Ankara Suture Zone (Şengör \& Yilmaz, 1981). The MMCC has recorded a complex and polyphase Pan-African, Variscan, and Alpine tectonometamorphic history (e.g., Catlos \& Çemen, 2005; Hetzel \& Reischmann, 1996; Lips et al., 2001; 


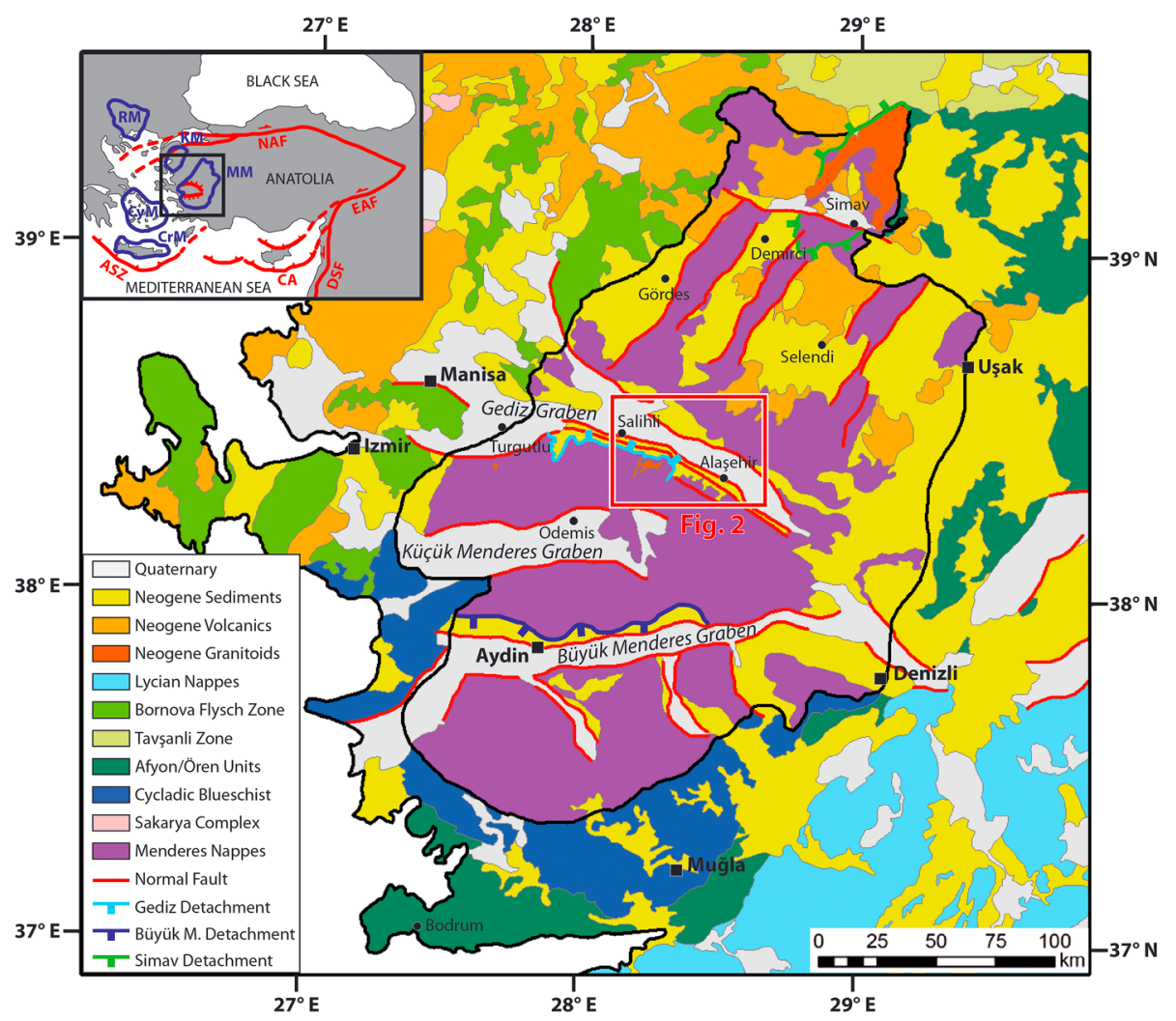

Figure 1. Schematic tectonic map of SW Turkey. The black line delimitates the Menderes Massif. The red box represents the location of the study area in Figure 2. The inset shows the main structures bounding the Anatolian plate (red lines) and the main metamorphic core complexes in the Aegean region (blue lines). Abbreviations: ASZ, Aegean Subduction Zone; CA, Cyprian Arc; CrM, Crete Massif; CyM, Cycladic Massif; DSF, Dead Sea Fault; EAF, East Anatolian Fault; KM, Kazdağ Massif; MM, Menderes Massif; NAF, North Anatolian Fault; RM, Rhodope Massif.

Oberhänsli et al., 2010; Ring et al., 1999; Ring \& Collins, 2005, and references therein) and has undergone extension and exhumation since the latest Oligocene (e.g., Gessner et al., 2001; Ring et al., 2003; Thomson \& Ring, 2006).

The earliest evidence of N-S extension in the Aegean region is recorded in the Rhodope massif in the Eocene (Brun \& Sokoutis, 2007; Burg, 2011; Dinter, 1998). N-S extension propagated later to the Central Aegean (Cyclades) and to the Menderes Massif during Oligo-Miocene times (see review in Jolivet and Brun, 2010). Total N-S extension is larger in the Aegean ( $350 \mathrm{~km}$; Gautier et al., 1999) than in the Menderes Massif ( $\sim 150 \mathrm{~km}$; van Hinsbergen, 2011). The overall Cenozoic extension in the Aegean region is related to the southward retreat of the Hellenic slab (Jolivet et al., 2012; Jolivet \& Brun, 2010; Jolivet \& Faccenna, 2000).

During the Neogene-to-Present extensional phase, three E-W trending syntectonic sedimentary basins developed in relation to faults that dissected the Menderes Massif into three submassifs (Figure 1). Apatite fission track data show distinct cooling ages for those three submassifs; the northern and the southern submassifs show ages ranging between the latest Oligocene and the middle Miocene (Gessner et al., 2013, 2001; Ring et al., 2003; Thomson \& Ring, 2006), whereas the central submassif shows ages mostly spanning between the late Miocene and the early Pleistocene (even if some early-middle Miocene cooling ages are preserved in its central part; Asti et al., 2018; Buscher et al., 2013; Gessner et al., 2001; Ring et al., 2003). These younger ages are limited to the footwall of the two major structures bounding the central submassif, namely, the Gediz Detachment to the nortN (also named Kuzey, Alaşehir, or Karadut Detachment) and the Büyük Menderes Detachment to the south (also named Güney or Basçayir Detachment; Figure 1). Two granodioritic bodies intruded the northern margin of the central submassif in the Burdigalian, namely, the Salihli and Turgutlu granodiorites, and are presently outcropping in the footwall of the ductile-to-brittle Gediz Detachment (Catlos et al., 2010, 2011; Glodny \& Hetzel, 2007; Hetzel, Ring, et al., 1995; Rossetti et al., 
2017). This magmatic event is thought to have triggered extensional detachment tectonics in this sector of the Menderes Massif at $14.6 \mathrm{Ma}$ (Rossetti et al., 2017).

Two categories of models have been proposed for the Oligo-Miocene exhumation of the Menderes Massif: (i) models arguing for symmetric bivergent exhumation through a southern and a northern detachment system (e.g., Bozkurt \& Park, 1994; Gessner et al., 2001; Hetzel et al., 1995; Ring et al., 2003) or (ii) models arguing for asymmetric exhumation via the north verging Simav Detachment system to the north (Figure 1; e.g., Gessner et al., 2013; Seyitoğlu et al., 2004). However, both categories of models consider that the central submassif was further symmetrically exhumed between the Serravallian and the early Pleistocene.

The formation of the Neogene-to-Quaternary Gediz Graben at the northern margin of the central submassif is related to the activity of the Gediz Detachment and of the other major normal faults bounding the southern and northern margin of the Central Menderes Massif (e.g., Asti et al., 2018; Çiftçi \& Bozkurt, 2009a; Cohen et al., 1995; Emre, 1996; Koçyiğit et al., 1999; Öner \& Dilek, 2011; Purvis \& Robertson, 2005a; Rossetti et al., 2017; Seyitoğlu et al., 2002). Detrital apatite fission track data show that the southern margin of the Gediz Graben experienced two major exhumation events, one involving the whole margin during late Miocene and one involving only its western part (Salihli area) during Plio-Quaternary times, thus generating a differential uplift of this sector (Asti et al., 2018). This differential exhumation is consistent with the differential evolution of slip rates on faults bounding the southern margin of the modern graben in response to fault segments interaction and linkage (Kent et al., 2016, 2017).

Firm age constraints for the onset of sedimentation and for the main sedimentary events are lacking. The age of the older sequence has been inferred to be early to middle Miocene based on palynological data (e.g., Ediger et al., 1996; Seyitoğlu \& Scott, 1992). More recently, well log (Çiftçi \& Bozkurt, 2009a) and detrital apatite fission track data (Asti et al., 2018) showed that the basin is likely not older than the middle Miocene. Çiftçi and Bozkurt (2009a) suggested that the basin developed as a half-graben with an active southern margin during the Miocene and changed its geometry due to the post-Miocene activation of its northern margin. Moreover, Çiftçi and Bozkurt (2010) proposed that the basin did not develop as a single trough since its early phases, but rather as a composite basin, formed by two/three subbasins that evolved independently and eventually linked in post-Miocene times.

\section{Materials and Methods}

\subsection{Field Data Collection}

We carried out field mapping at a 1:25.000 scale along the southern margin of the Gediz Graben, between Salihli (to the west) and Alaşehir (to the east; Figure 2). We constructed stratigraphic logs and collected structural measurements to define the tectonostratigraphic evolution of the basin.

In this study, for the subdivision of the lithostratigraphic units of the Gediz Graben we use the nomenclature proposed by Çiftçi and Bozkurt (2009a) based on an early stratigraphic scheme (i.e., İztan \& Yazman, 1991), to avoid complications due the introduction of different stratigraphic names in later studies (i.e., Çiftçi \& Bozkurt, 2009a; Cohen et al., 1995; İztan \& Yazman, 1991; Koçyiğit et al., 1999; Öner \& Dilek, 2011; Purvis \& Robertson, 2005a; Sarıca, 2000; Seyitoğlu et al., 2002; Yılmaz et al., 2000). According to this subdivision, four lithostratigraphic formations (Fm) crop out at the southern margin of the basin. They are (from bottom to top) the conformable Alaşehir Fm, Çaltilik Fm, and Gediz Fm, and the unconformably overlying Kaletepe Fm (Figure 3).

Measurements of foliation and stretching lineation were collected in the Gediz Detachment shear zone, in the weakly deformed part of the Salihli granodiorite and in the Menderes metamorphic basement. Measurements of fault surfaces and associated slickenlines were collected on low-angle normal faults in the Alaşehir area and in high-angle normal faults affecting the bedrock and the Neogene sedimentary units. In section 4, we first present the stratigraphic results and then the results of structural analysis.

\subsection{Sampling Strategy and Samples Preparation for Micropaleontological Analyses}

In order to obtain chronostratigraphic constraints for the evolution of the Gediz Graben sedimentary fill, about 30 samples in the whole stratigraphic succession were collected for micropaleontological analysis, 


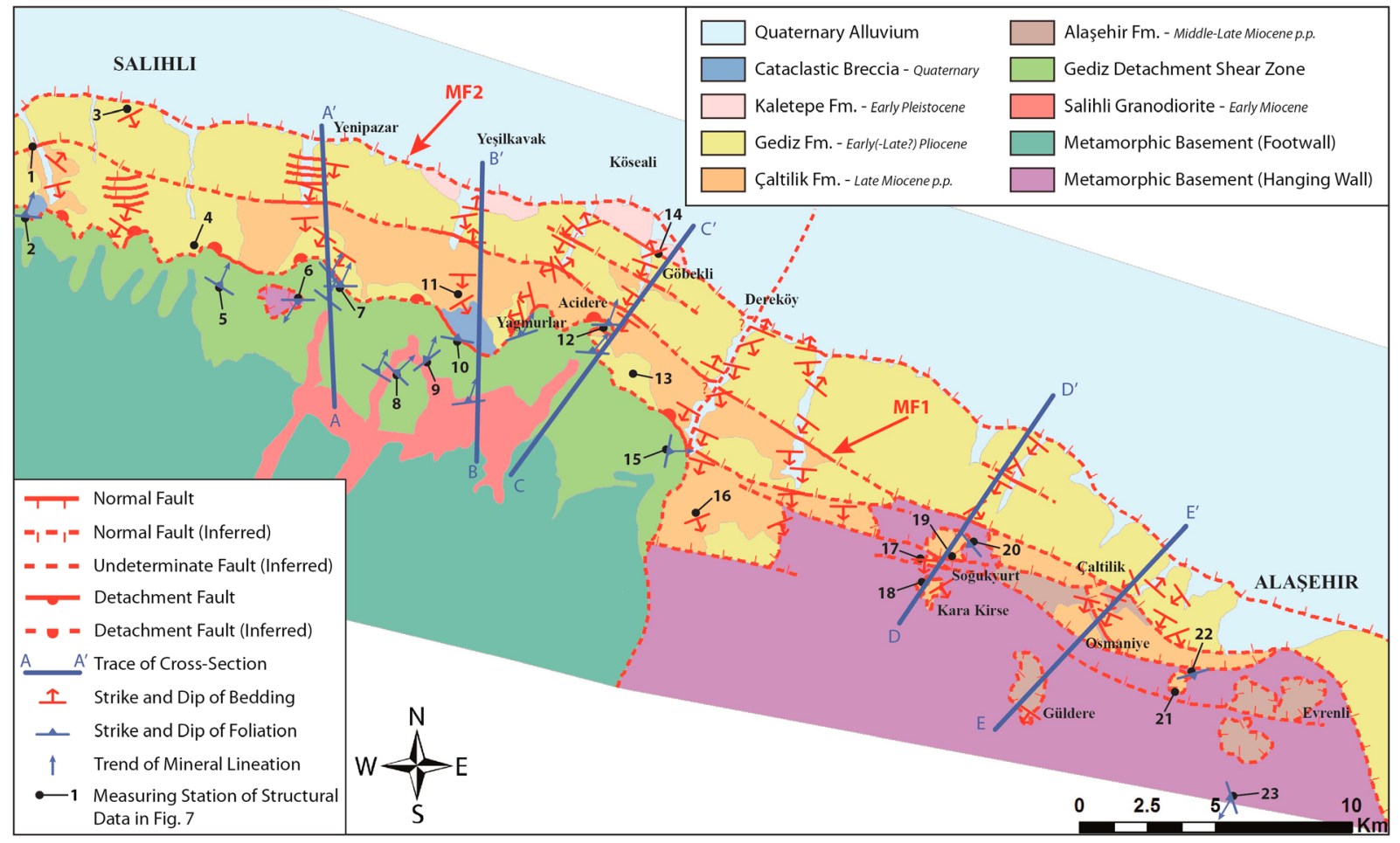

Figure 2. Geological map of the southern margin of the Gediz Graben between Salihli (to the west) and Alaşehir (to the east). Thick blue lines show the locations of the geological cross sections represented in Figure 8.

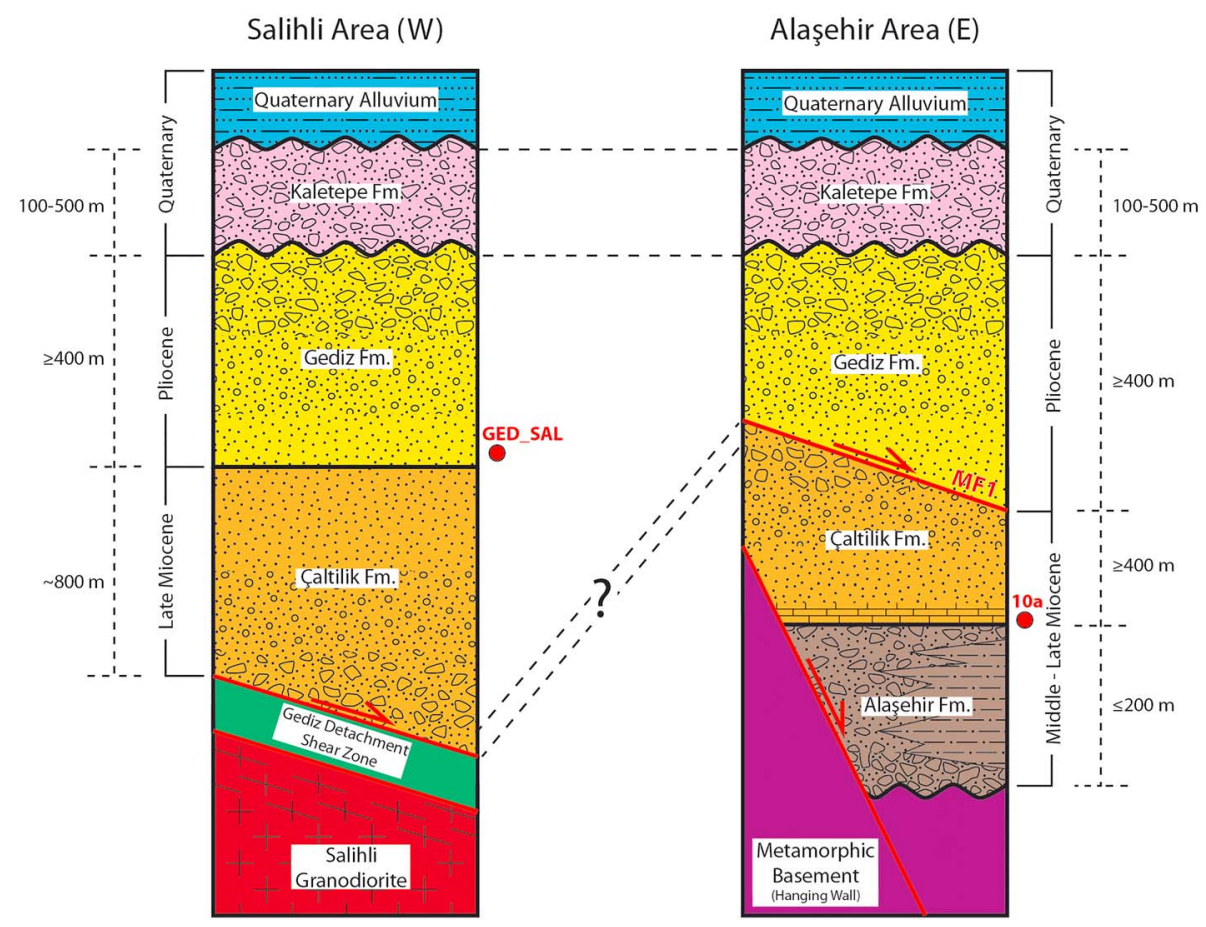

Figure 3. Stratigraphy of the Neogene-to-Quaternary sedimentary fill of the Gediz Graben in the study area. On the left the stratigraphic pattern of the Salihli area (western sector) and on the right the one of the Alaşehir area (eastern sector); dashed black lines between the two columns show possible correlations between the two sectors. Undulating black horizontal lines between two formations indicate angular unconformities. Unconformity at the base of the Alașehir Fm is not visible in outcrop but is imaged by seismic reflection profiles in the area (see Çiftçi \& Bozkurt, 2010). 
from the fine-grained levels (shales and silts) of the whole stratigraphic succession and from a limestone at the base of the Çaltilik Fm.

The poorly or noncemented fine-grained samples were washed and disaggregated in an hydrogen peroxide solution $(5 \% \mathrm{vol})$ and then sieved under running water through $500-, 125-$, and $63-\mu \mathrm{m}$ mesh sieves. The resulting sediment fractions were dried at $50{ }^{\circ} \mathrm{C}$ and then analyzed under a stereomicroscope.

Limestone from the Çaltilik Fm was analyzed in thin section to first assess the potential fossil content; then the samples with positive results were selected for disaggregation. These rocks are very cohesive, so a disaggregation technique that is comparable with natural weathering that makes use of sodium thiosulfate pentahydrate $\left(\mathrm{Na}_{2} \mathrm{~S}_{2} \mathrm{O}_{3} \cdot 5 \mathrm{H}_{2} \mathrm{O}\right.$, commonly and improperly called sodium hyposulphite) was used, as described in Tinn and Meidla (1999, and references therein). This salt melts at $48{ }^{\circ} \mathrm{C}$ and crystallizes pretty easily below this temperature, if seed crystals are present.

About 300-400 g of limestone for each sample were mechanically crushed into 1-2-cm size pieces; a comparable amount, in terms of volume, of thiosulfate was added; then the compound was heated on a stove to melt the salt and finally was cooled for few hours at room temperature to let the salt crystallize again. The cycle was repeated about 30 times for each sample in order to obtain a suitable amount of fine crushed material. After this treatment, the samples were drowned in Rewoquate ${ }^{\circledR}$ WE15 and then sieved under running water through 2-cm, 500-, 125-, and 63- $\mu \mathrm{m}$ mesh sieves. The resulting sediment fractions were dried at $50{ }^{\circ} \mathrm{C}$, and the fractions between 500 and $125 \mu \mathrm{m}$ were analyzed under a stereomicroscope.

\section{Basin Stratigraphy}

In the following, we will present our results from the lower to the upper stratigraphic units and illustrate the differences between the western (Salihli area) and eastern (Alaşehir area) sectors of the study area (Figures 2 and 3). The proposed thicknesses for the formations described below are likely biased by the large number of synsedimentary and postsedimentary minor faults that affected the sedimentary sequence (see section 6.3).

\subsection{Alaşehir Formation}

The Alaşehir Fm is the lowermost Neogene lithostratigraphic formation cropping out at the southern margin of the Gediz Graben and represents the first and oldest sedimentary unit of the basin. This formation crops out only in the eastern part of the study area and particularly in proximity of the town of Alaşehir. According to Çiftçi and Bozkurt (2009a), it is composed of two interfingering members (Mbr), the coarser Evrenli Mbr and the finer Zeytinçayi Mbr.

In the study area, the Evrenli Mbr is exposed in the area around the Evrenli village (to the south of the town of Alaşehir; Figure 2), showing a fining-upward trend. The lower part consists of well-cemented, unsorted, and reddish matrix-supported conglomerates (Figure 4a and supporting information Figure S1a), with angular to subrounded clasts, from millimeter to meter sized, lying within a sandy matrix. The upper part of this member mainly consists of bedded sandstones, pebbly sandstones, and minor siltstones (Figure $4 \mathrm{~b}$ and supporting information Figure S1d) with parallel and convolute laminations, locally associated with fluidexpulsion structures. Pebbles derive from metamorphic rocks, mostly gneiss, schist, quartzite, and marble. This member seems to display an overall fining upward trend.

The finer Zeytinçayi Mbr is exposed extensively to the north and to the south of Osmaniye village, to the SW of the town of Alaşehir. This member is mainly represented by alternations of well-bedded, grayish-toyellowish, finely laminated clayey siltstones (Figure $4 \mathrm{~b}$ and supporting information Figure S1b), organicrich shales, and silty sandstones. In the finer-grained layers, vegetal fragments and oxide nodules (Figure $4 \mathrm{~b}$ and supporting information Figure S1c) are quite frequent. The coarser sandy layers generally show an internal normal grading.

The upper limit of the Alaşehir Fm is always marked by alternating yellowish stratified cross-bedded sandstones and pebbly sandstones, with pebbles ranging from $\mathrm{cm}$ to $\mathrm{dm}$ in size (Figure $4 \mathrm{c}$ and supporting information Figure S2a). Occasionally and only in this upper portion, pebble imbrication in the coarser component is detectable, possibly pointing to a mean NE paleocurrent direction.

The thickness of the Alaşehir Fm is hard to estimate due to internal syndepositional and postdepositional faulting (supporting information Figure S1e), but its maximum thickness in outcrop should not exceed 

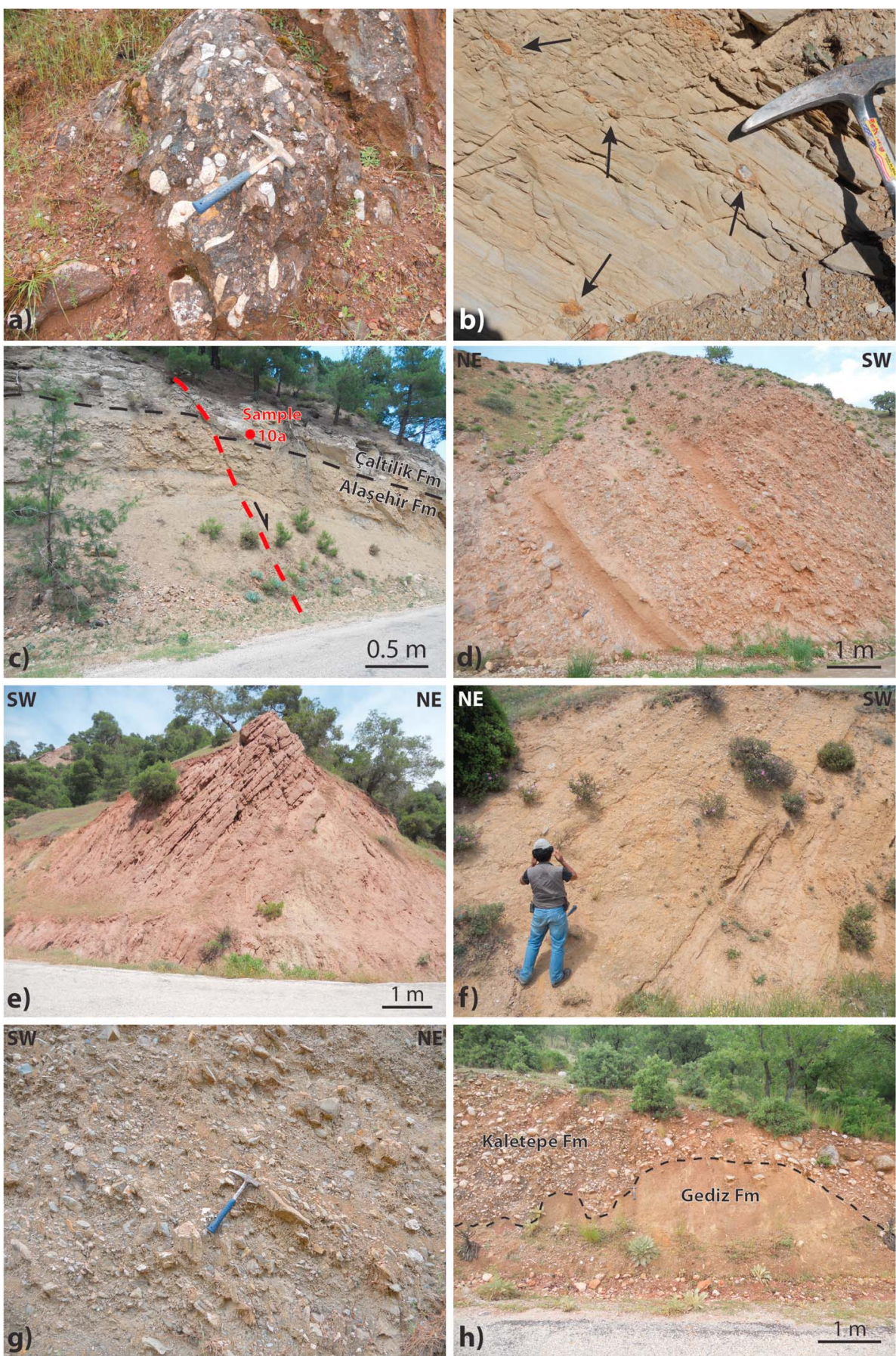

Figure 4. Outcrop pictures showing some characteristic features of the Neogene-to-Quaternary basin fill. (a) Wellcemented conglomerate in the Evrenli Mbr of the Alaşehir Fm (note that all the clasts are derived from metamorphic lithologies). (b) Laminated silts of the Zeytinçayi Mbr of the Alaşehir Fm (oxide nodules indicated by black arrows). (c) Stratigraphic limit between stratified sandstones and conglomerates of the Alaşehir Fm (below) and the irregularly stratified limestone at the base of the Çaltilik Fm (above); the red circle shows the location of sample 10a characterized by an upper Tortonian shallow marine faunal assemblage (Section10, between Soğukyurt and Kara Kirse villages; see text for further explanations). (d) Conglomerate and sandstone layers of the lower part of the Çaltilik Fm outcropping in the eastern part of the study area (Alaşehir area). (e) Sandstone layers in the upper part of the Çaltilik Fm (Salihli area). (f) Finer-grained (sandstones and minor conglomerates) lower part of the Gediz Fm. (g) Coarser-grained (conglomerates and minor sandstones) in the upper part of the Gediz Fm. (h) Stratigraphic erosional contact between the Gediz Fm (below) and the Kaletepe Fm (above). See supporting information Figures S1 to S5 for more details on the characteristic features of the stratigraphic formations in outcrop. 
$200 \mathrm{~m}$. This unit does not show evidence of growth or thickening toward the $\mathrm{S}$ and therefore its deposition was not controlled by fault activity at the southern margin of the basin. Its thickness can be more than $1,000 \mathrm{~m}$ in the central part of the basin (see Çiftçi \& Bozkurt, 2009a; Çiftçi \& Bozkurt, 2010).

\section{2. Çaltilik Formation}

The Çaltilik Fm conformably overlies the Alaşehir Fm and is exposed extensively all along the southern margin of the study area, with major differences between the Salihli and the Alaşehir areas. The base of this formation crops out only in the Alaşehir area, particularly near Soğukyurt, Osmaniye, and Çaltilik villages (Figure 2). It consists of an irregularly bedded, decametric thick, grayish-to-yellowish limestone interval (Figure 4c and supporting information Figure S2). The limestone sequence consists of regularly (supporting information Figure S2b) to irregularly bedded ( supporting information Figure S2c) wakestones and minor packstones, rich in extraclasts and bioclastic fragments and minor well-preserved bioclasts, such as foraminifer and ostracod shells. To the top, the limestones gradually pass to continental red sandstone layers, with alternations of decimetric calcareous layers and metric red arenaceous layers with calcareous cement (supporting information Figure S2d). The total thickness of this limestone interval does not exceed a few tens of meters.

In the Alaşehir area, above the limestone interval, this formation includes mainly sandy red layers with muddy matrix and minor gravelly intervals, with sedimentary structures such as horizontal lamination and low-angle cross lamination. These layers are generally poorly sorted and polymictic, with pebbles derived from the metamorphic lithologies of the Menderes Massif. In this sector, this formation shows a coarsening upward trend, from mainly arenaceous deposits to mainly matrix-supported conglomeratic red layers with a sandy/silty matrix (Figure $4 d$ and supporting information Figures S3a and S3b). In the upper part, exposed extensively on the eastern flank of the Dereköy valley, clasts are rounded to subangular, ranging from gravel to boulders in size and are still derived exclusively from metamorphic lithologies. Clast imbrication suggests a NNE directed transport. In this area, the total thickness of the Çaltilik Fm likely exceeds $400 \mathrm{~m}$.

In the Salihli area the red clastic deposits of the Çaltilik Fm tectonically overlie the surface of the Gediz Detachment, but the calcareous layer at the base of this formation is not present in outcrop; in contrast to what is observed in the Alaşehir area, here these deposits show a fining upward trend. The lower and coarser member is well exposed to the $\mathrm{S}$ of the Acidere village (Figure 2), in the footwall of the MF1 fault (see section 6.3), and consists of poorly sorted, mainly conglomeratic, matrix supported, red layers with minor silty/sandy layers (supporting information Figures S3c and S3d); the clasts, always derived from the Menderes metamorphic basement, are angular or subangular, with centimetric to decimetric size. The upper part of the formation is characterized by a marked decrease in the mean grain size and is represented by mainly arenaceous red layers, sometimes with gravel intercalations, and minor siltstone/mudstone layers (Figure 4e and supporting information Figures S3e and S3f); cross laminations are characteristic of arenaceous layers, while fine-grained layers might preserve parallel laminations. In places, clast imbrication suggests a NNE sediment transport direction. In this area, the exposed section of the Çaltilik Fm reaches a maximum value of about $800 \mathrm{~m}$.

Due to the lack of suitable marker horizons such as volcanic layers or biochronologically constrained levels, no straightforward correlations could be made between portions of the Çaltilik Fm preserved in the eastern and western sectors of the study area. We suggest, dubitatively, that the stratigraphically higher and coarser deposits outcropping in the eastern sector might be correlated with the lower and coarser part outcropping in the western sector (see Figure 3). If this interpretation is correct, this would mean that the older portion of the Çaltilik Fm is mainly exposed in the Alaşehir area, whereas the Salihli area only includes the upper part of the formation.

\subsection{Gediz Formation}

The transition to the overlying Gediz Fm is seldom visible in outcrop. It is not sharp but is rather represented by a gradual change in color in the upper part of the Çaltilik Fm, which gradually passes from light red to grayish/yellowish moving upsection. This relationship between the two formations is clearly visible when approaching Yağmurlar village, moving from north to south (Figure 2). In general, the Gediz Fm shows an overall coarsening upward trend. The lower part is more fine grained and mainly represented by 
yellowish/brownish, cross-bedded, sandy, and silty layers with gravel intercalations (Figure 4f and supporting information Figures S4a-S4c); pebbles are generally well sorted, centimeter to decimeter in size, rounded to subrounded and exclusively derived from metamorphic lithologies of the Menderes Massif. In the lowermost part of this formation, decimeter-thick layers of organic-rich dark shale with gypsum crystals and ostracod and gastropod fragments are also present (well exposed to the south of the town of Salihli; supporting information Figures S4c and S4d). The upper part of this formation is dominated by yellowish/brownish matrix supported conglomerates, intercalated with minor sandy and silty layers (Figure 4g and supporting information Figures S4e and S4f). Clasts are subrounded to subangular and still derived exclusively from the metamorphic basement; imbrication of the clasts shows a variable transport direction, ranging between NE and NW. No major differences in the Gediz Fm were observed between the western and the eastern sector of the study area. The thickness of this formation likely exceeds $400 \mathrm{~m}$.

The lithological differences between the Çaltilik Fm and the Gediz Fm, with the notable exception of the basal limestone, are not striking. Both formations were deposited in a continental alluvial environment (Çiftçi \& Bozkurt, 2009a; Öner \& Dilek, 2011; this study). In the field, they can be distinguished as the older one shows a distinctive reddish color, while the younger one shows a yellowish/brownish/grayish color. This difference is due to syndiagenetic oxygenated groundwater circulation (e.g., Mücke, 1994; Van Houten, 1973; Walker, 1967) particularly intense in the older deposits. This process is, however, not expected to affect the whole basin uniformly, and the transition between the two units is indeed a gradual transition. Therefore, the boundary between these two formations may be time transgressive.

\subsection{Kaletepe Formation}

The Kaletepe Fm is the highest and youngest formation predating the modern Gediz Graben sedimentary fill. It outcrops to the south of the Yeşilkavak and Köseali villages (Figure 2), right at the footwall of the active fault presently bounding the alluvial plain (MF2 fault; see section 6.3) and unconformably overlies the older formations (Figure $4 \mathrm{~h}$ and supporting information Figure S5a). The Kaletepe Fm is represented by brownish, mainly conglomeratic, poorly bedded deposits with a silty matrix. In this formation the subrounded to subangular clasts are derived not only from the Menderes metamorphic bedrock but also from the underlying Çaltilik Fm and Gediz Fm and from the Gediz Detachment (supporting information Figures S5b-S5d). This suggests that at the time of deposition of the Kaletepe Fm, the rocks of the older basin fill were already exhumed and being eroded.

We observed only a small portion of the Kaletepe Fm in outcrop, which is less than $100 \mathrm{~m}$ thick. Previous studies (e.g., Çiftçi \& Bozkurt, 2009a; Öner \& Dilek, 2011) suggest that this formation may be thicker (up to $\sim 500 \mathrm{~m})$.

\section{Micropaleontological Analyses}

Among the 18 shale and silt samples collected in the Alaşehir Fm, Çaltilik Fm, Gediz Fm, and Kaletepe Fm, only sample GED_SAL, from the lower Gediz Fm, yielded some fossil remains, while all the others were barren. Sample GED_SAL was collected in the lower part of the Gediz Fm, right to the south of the town of Salihli (N 38 $28^{\prime} 15.5^{\prime \prime}$, E $028^{\circ} 08^{\prime} 29.0^{\prime \prime}$ ), in an 30-cm-thick layer of dark shale with abundant organic matter, vegetal remains, shell fragments, and gypsum crystals embedded in the matrix (supporting information Figures S4c and S4d). The outcrop is cut by a number of small-offset conjugate normal faults (supporting information Figure S4c). The stratigraphic level of this layer should be close to the one reported by Emre (1996) as bearing Dacian (Mio-Pliocene boundary) continental gastropods near the village of Yağmurlar ( 20 km to the SE). In sample GED_SAL, some ostracod shells, entire or in fragments, and some gastropod fragments have been found. Unfortunately, all the well-preserved ostracod shells represent only young specimens related to the genus Candona, only confirming the continental depositional setting.

We sampled the limestone at the base of the Çaltilik Fm between the villages of Soğukyurt and Kara Kirse (Section10; Figure 4c and supporting information Figure S2a), where the limit with the lower Alaşehir Fm is exposed, and many other outcrops along the eastern sector of the study area. After thin section analysis (supporting information Figure S7), three samples from Section10 were disaggregated by sodium thiosulfate pentahydrate, but only one of them (sample 10a) yielded a small, but significant, number of ostracods and planktonic foraminifera (Figure 5). 


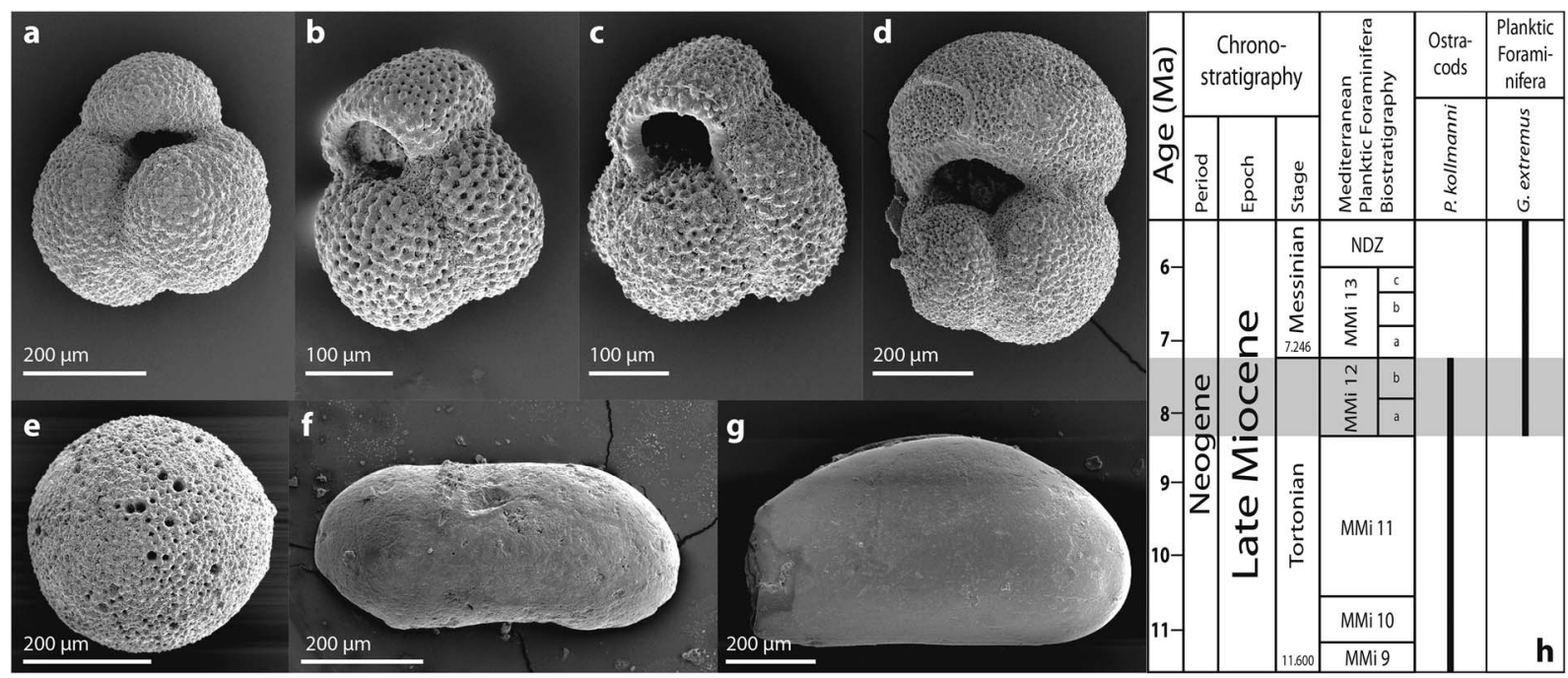

Figure 5. SEM photographs of foraminifera and ostracods retrieved from sample 10a (Section10, Çaltilik Fm, between Soğukyurt and Kara Kirse villages: $\mathrm{N}_{38^{\circ}} 21^{\prime}$

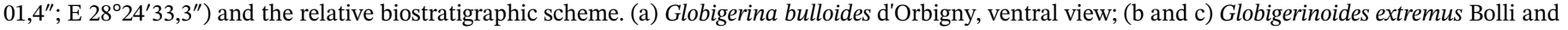
Bermudez, ventral view; (d) Globigerinoides quadrilobatus (d'Orbigny), ventral view; (e) Orbulina universa d'Orbigny, ventral view; (f) Pseudopsammocythere kollmanni Carbonnel, right valve, external view; (g) internal mold of ostracod, dubitatively related to the genus Cyprideis. (h) Mediterranean biostratigraphic scheme for the late Miocene with the distribution of biostratigraphically useful species recovered in sample 10a. The light gray horizontal band show the proposed age interval for sample 10a (i.e., overlapping period for the distribution of G. extremus and P. kollmanni). Mediterranean planktic foraminifera biostratigraphy from Iaccarino et al. (2007). NDZ = nondistinctive zone.

In sample 10a, six different species of surprisingly well-preserved marine planktonic Foraminifera have been recognized: Globigerina bulloides d'Orbigny (Figure 5a), Globigerinoides extremus Bolli and Bermudez (Figures 5b and 5c), Globigerinoides quadrilobatus (d'Orbigny; Figure 5d), Orbulina universa d'Orbigny (Figure 5e), Globigerinoides obliquus Bolli, and Globoturborotalia druryi (Akers). In addition, we found a few ostracod remains also including a single right valve with preserved shell identified as Pseudopsammocythere kollmanni Carbonnel (Figure 5f) and few internal molds of other undetermined ostracod species, dubitatively related to the genus Cyprideis (Figure 5g).

Among all these species, only G. extremus and P. kollmanni are biostratigraphically useful, with the latter also providing information on the possible bathymetry of the depositional setting of the limestone at the base of the Çaltilik Fm. G. extremus is distributed from the uppermost Tortonian (base of the MMi 12a biozone) to the lowermost Pleistocene (top of the MPl 5a biozone; Iaccarino et al., 2007). In general, P. kollmanni is distributed from the upper Langhian to the Tortonian in marine shelf deposits, from circalittoral to external infralittoral environments (see Appendix A for details). The coexistence of G. extremus and P. kollmanni in the faunal assemblage points to a possible upper Tortonian age (MMi 12 biozone, i.e. 8.35-7.246 Ma) for the limestone at the base of the Çaltilik Fm (Figure 5h), possibly in a 50-150-m deep marine shelf environment.

\section{Structural Analysis}

Major differences exist in the structural pattern of the southern margin of the basin between the western (Salihli area) and eastern (Alaşehir area) sector of the study area, especially for what concerns the southernmost structures (Figures 2 and $6 \mathrm{~h}$ ).

\subsection{Structure of the Basin Margin in the Salihli Area: The Gediz Detachment}

The Salihli area is morphologically dominated by the N-to-NE gently dipping Gediz Detachment Fault, which represents the southern margin of the basin in this sector (Figures 2 and 6a). This structure has been extensively described (e.g., Çemen et al., 2005; Hetzel, Ring, et al., 1995; Işik et al., 2003; Rossetti et al., 2017; Sarikaya, 2004; Seyitoğlu et al., 2000, 2015). 

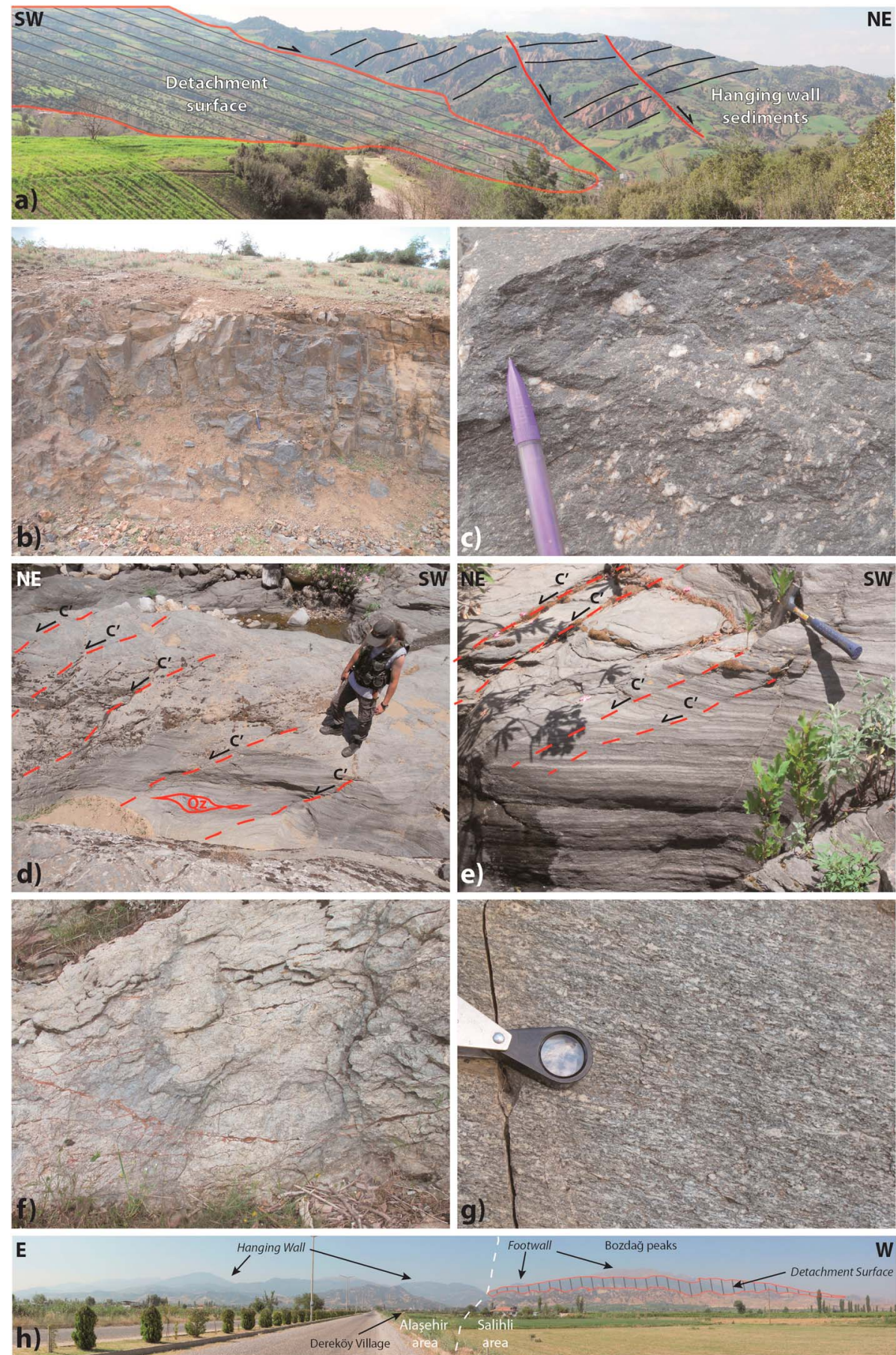

Figure 6. Outcrop pictures showing some characteristic features of the Gediz Detachment and of the Salihli granodiorite. (a) Landscape view of the gently NE dipping Gediz Detachment surface (to the left) with Neogene sediments at the hanging wall (to the right) tilted toward the SW. (b) Outcrop view of the structurally uppermost ultracataclastic layer. (c) Detail of the ultracataclastic layer with macroscopic quartz fragments. (d) Large quartz porphyroclasts and $\mathrm{C}^{\prime}$ planes cutting the mylonitic foliation in the upper ductile layer. (e) $\mathrm{C}^{\prime}$ planes cutting the mylonitic foliation in the upper ductile layer. (f) Chlorite Breccia; note diffused fracturing and green color of the rock due to pervasive chloritization. (g) Gneissic fabric of the Salihli granodiorite in the lowermost layer of the Gediz Detachment. (h) Landscape view of the southern margin of the Gediz Graben; on the right (west) the NE dipping Gediz Detachment and its footwall (with the Bozdağ peaks), on the left (east) the Menderes metamorphic bedrock in the hanging wall of the detachment. The dashed white line corresponds to the Dereköy valley, which marks the limit between the Alaşehir area (to the east) and the Salihli area (to the west). 
The dip of the detachment surface is gentle, between $10^{\circ}$ and $30^{\circ}$ (green box in Figure 7). The stretching lineation, as provided by quartz-biotite aggregates in the shear zone of the detachment, trends mainly $\mathrm{NNE}$, varying generally between $\mathrm{N} 20^{\circ}$ and $\mathrm{N} 40^{\circ}$, with a sense of shear always top-to-the-NNE. An exception is represented by the easternmost outcrop area of the detachment surface (western side of the Dereköy valley), where the foliation plunges to the east and the direction of the stretching lineation turns abruptly to the east, with a mean direction around $\mathrm{N} 90^{\circ}$ (Figure 7 , station 15). The mylonitic foliation and the detachment surface itself dip on average to the NNE, but it is folded by gentle antiformal and synformal folds with axes that are parallel to the stretching direction on an overall convex-up detachment surface, thus defining a corrugated turtleback structure (Çemen et al., 2005; Seyitoğlu et al., 2015).

High-angle normal faults in the hanging wall, cutting the Neogene-to-Quaternary basin fill, root into the detachment surface. This observation is consistent with seismic reflection profiles showing high-angle normal faults rooting on the Gediz Detachment at depth in the Alaşehir area (Çiftçi \& Bozkurt, 2008, 2010; Demircioğlu et al., 2010; Yllmaz \& Gelişli, 2003). Major synclines and anticlines in the hanging wall, with axes near parallel to the strike of the detachment, may reflect the ramp-flat geometry of the detachment surface at depth (e.g., Gibbs, 1984; Figure 8 A-A', B-B', and C-C' cross sections).

The Gediz Detachment consists of a ductile-to-brittle shear zone with variable thickness generally not exceeding $\sim 100 \mathrm{~m}$. The shear zone can be described as a mylonite with cataclastic overprint that gradually transitions upward into a very fine grained ultracataclasite (Hetzel, Ring, et al., 1995; Işik et al., 2003; Rossetti et al., 2017). In detail, from top to bottom, the Gediz Detachment structure is characterized by (i) a dark, fine-grained ultracataclastic layer with quartz and chlorite veins and, occasionally, macroscopic quartz fragments in its lower part with evidence for cataclastic flow (Figures 6b and 6c); (ii) a dark gray phyllonite with cm-sized quartz fragments (Figures $6 \mathrm{~d}$ and 6e); (iii) a chlorite breccia, made of a cataclasite cemented by quartz and chlorite veins and minor oxide and calcite mineralizations (Figure 6f); (iv) a top-tothe-NE mylonite horizon with gneissic texture made of porphyroclastic feldspar embedded in a matrix made of recrystallized quartz-feldspar-biotite \pm amphibole (Figure $6 \mathrm{~g}$ ), formed at the expenses of the Salihli Granodiorite. The footwall of the detachment is constituted by the undeformed Salihli Granodiorite (outcropping only between the Yeşilkavak and Göbekli valleys).

A small klippe of hanging wall metamorphic basement is preserved above the detachment surface $\sim 7 \mathrm{~km}$ to the south of Yenipazar (Figure 2). Its internal foliation dips southwestward and represents the only remnant of the hanging wall metamorphic basement in the whole Salihli area.

\subsection{Structure of the Basin Margin in the Alaşehir Area}

In the Alaşehir area, the morphology of the southern margin of the basin is controlled by NE dipping normal faults with a step-like pattern (Figure 2). The most southerly structure is represented by isolated remnants of a gently dipping (between $15^{\circ}$ and $30^{\circ}$ ) fault surface (slickenside; brown box in Figure 7 and supporting information Figure S8), with NE trending slickenlines, which separates the metamorphic rocks of the Menderes Massif in the footwall from the older formations of the Gediz Graben sedimentary fill (i.e., Alaşehir Fm and Çaltilik Fm). In contrast with the footwall of the Gediz Detachment, here no clear ductile S-L fabric related to a top-to-the-NE extensional shear was observed, but only brittle features (such as fractures, slickenlines, and cataclasite; supporting information Figures S8e and S8f). Here the most southerly fault surface is cut and displaced by younger high-angle normal faults, which is not the case for the Gediz Detachment in the Salihli area.

In the Menderes metamorphic units at the southern margin of the graben, foliation always dips between south and SW (purple box in Figure 7), with a stretching lineation parallel to the one observed on the mylonitic shear zone of the Salihli area, but with sense of shear either pointing to the NE or to the SW.

\subsection{High-Angle Brittle Faulting and Synsedimentary Faults}

To the north of the Gediz Detachment, a series of subparallel high-angle normal faults are clearly visible at the outcrop scale, with dip angles generally decreasing from north to south and ranging from $\sim 45^{\circ}$ for the more southerly to $\sim 70^{\circ}$ for the more northerly structures (yellow box in Figure 7). Among all these structures two major normal faults affect the entire length of the study area (Figure 2): (1) the southernmost fault (MF1 in Figure 2) separates an area mainly characterized by outcrops of the Gediz Fm to the north (in the hanging wall), from an area mainly characterized by exposures of older deposits to the south (also known as the 


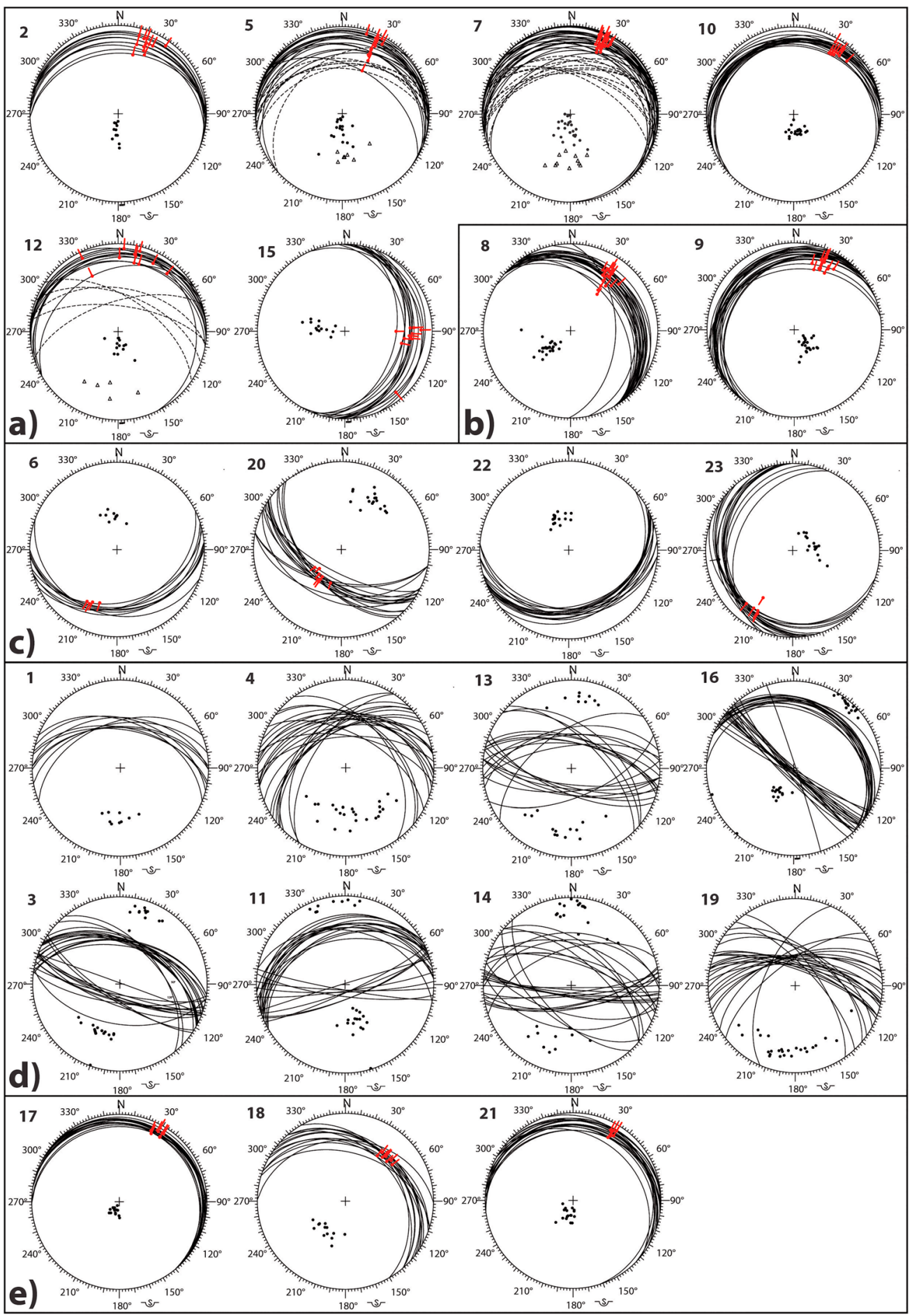

Figure 7. Stereoplots (equal-area Schmidt net, lower hemisphere projection) of measured structural features in the study area. Numbers in bold on the stereoplots refer to the number of the measuring station indicated in the map in Figure 2. (a) Mylonitic foliation (solid lines), stretching lineation (red lines), and $\mathrm{C}^{\prime}$ planes (dashed lines) measured in the Gediz Detachment Shear Zone. (b) Mylonitic foliation (solid lines), stretching lineation (red lines) measured in the Salihli granodiorite. (c) Mylonitic foliation (solid lines), stretching lineation (red lines) measured in the metamorphic basement in the hanging wall of the Gediz Detachment. (d) High-angle brittle normal faults (solid lines) cutting both the basin sedimentary fill and the metamorphic bedrock. (e) Low-angle brittle normal fault surfaces (solid lines) separating the metamorphic basement and the sedimentary fill of the basin in the eastern part of the study area and relative slickenlines (red lines). In a-c, black dots are pole to foliation and triangles are poles to $\mathrm{C}^{\prime}$ planes. In $\mathrm{d}$ and e, black dots are pole to faults. 

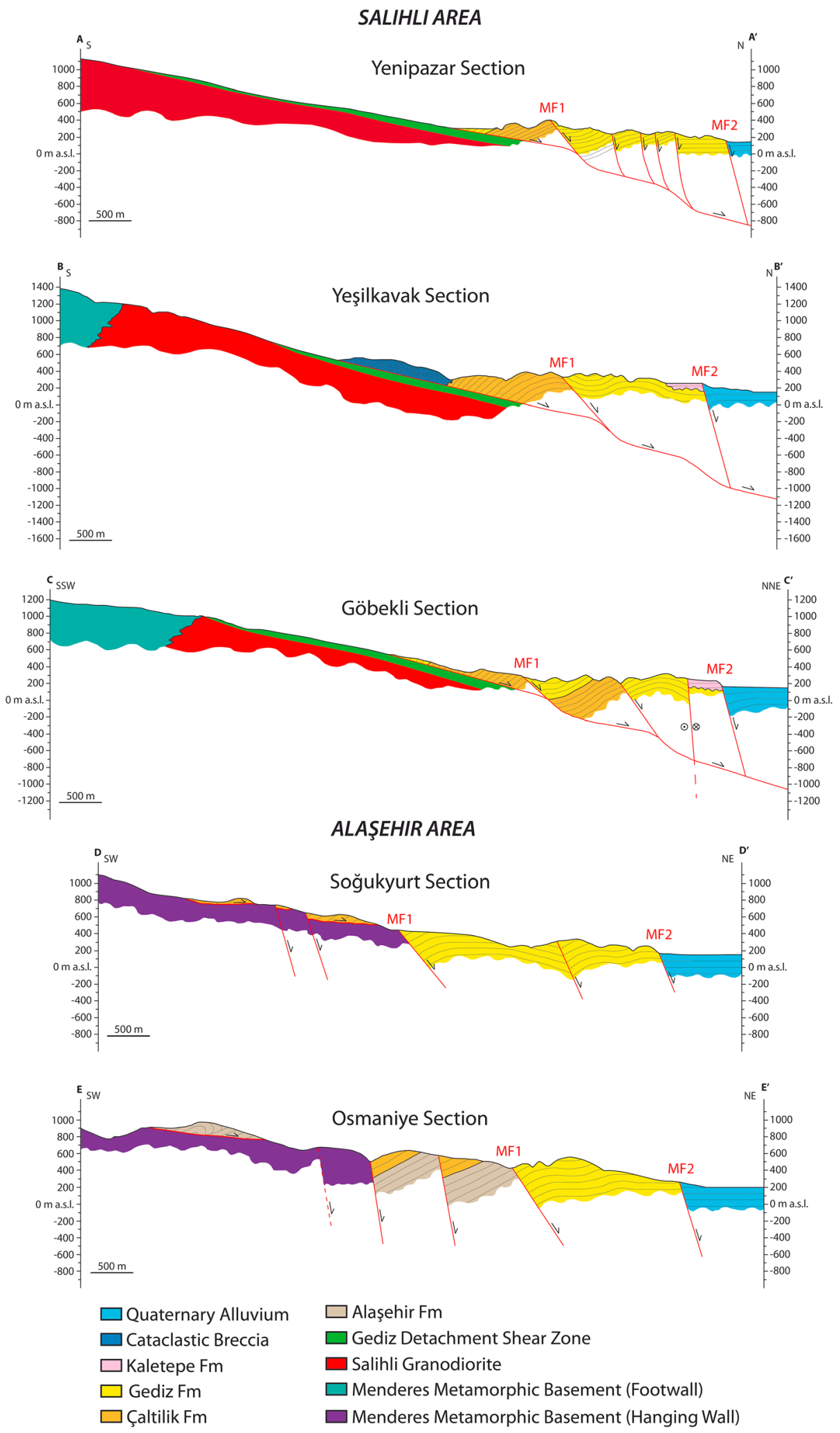

Figure 8. Geological cross sections across the southern margin of the Gediz Graben (see Figure 2 for locations). Highangle brittle faults cutting the basin sedimentary fill root into the detachment, rather than crosscutting it. High-angle brittle faults in the eastern part of the study area cut and displace low-angle brittle fault surfaces. Major sinforms and antiforms in sediments in the hanging wall of the detachment, with axes almost parallel to the strike of the detachment, are interpreted as reflecting the ramp-flat geometry of the detachment surface at depth. 
Master Graben Bounding Fault of Çiftçi and Bozkurt, 2009a, and Çiftçi and Bozkurt, 2009b, or Acidere Fault of Öner and Dilek, 2011) and has a NNW to NW direction, a dip of $\sim 45^{\circ}$ and normal kinematic; (2) the northernmost (MF2 in Figure 2) is the active normal fault bounding the present-day alluvial plain, separating Quaternary deposits to the north (hanging wall) from exposed ancient basin fill to the south (footwall).

A large number of minor and segmented normal faults exist between these two major faults and to the south of MF1 in the Alaşehir area. These structures define a step-like morphology that is characteristic of the southern margin of the graben (Bozkurt \& Sözbilir, 2004; Çiftçi \& Bozkurt, 2009b; Koçyiğit et al., 1999; Seyitoğlu et al., 2002).

In the western part of the study area, to the south of the town of Salihli and of Yenipazar village, there is evidence for postsedimentary E-W trending domino faulting involving deposits of the Gediz Fm in the hanging wall of the Gediz Detachment. The spacing between the faults bounding the tilted blocks is on the order of a few hundred meters.

Evidence for synsedimentary fault activity is widespread. In the area close to Evrenli village, immediately south of the town of Alaşehir, it is possible to observe synsedimentary faults confined in the coarser member of the Alaşehir Fm (Evrenli Mbr), with a variable offset that decreases upsection. Synsedimentary fault activity is recorded in the basin fill by the presence of growth strata (e.g., in the Çaltilik Fm and in the Gediz Fm; Figures $9 \mathrm{a}$ and $9 \mathrm{~b}$ ) and by intraformational conjugate fault systems. Conjugate normal fault systems in the Çaltilik Fm and in the Gediz Fm are generally tilted southwestward (supporting information Figures S3f, S4b, and S4c). In places, the thickness of the Gediz Fm strata increases slightly close to MF1. In general, due to small offsets, no change is sedimentary facies is observed in relationship with synsedimentary faults.

In the fine-grained member of the Alaşehir Fm (Zeytinçayi Mbr), especially in the area between Güldere and Osmaniye villages, many deformation structures oriented parallel to the basin margin can be observed, such as antiformal and synformal folds (from submetric to decametric in amplitude), normal faults, and north verging thrust faults (Figure $9 \mathrm{c}$ and supporting information Figure S1e). These structures are often associated with small-scale slumps and have been related to tectonic instabilities during extension in the early phases of basin formation (Şengör \& Bozkurt, 2013; this study).

Evidence for recent strike-slip fault activity is observed in places on the southern margin of the alluvial plain. At the northern end of the Göbekli valley, $1 \mathrm{~km}$ to the north of the Göbekli village (Figure 2), a nearly vertical E-W trending fault plane is visible in outcrop, separating deposits of the Kaletepe Fm to the north from deposits of the Gediz Fm to the south (supporting information Figure S5e); almost horizontal slickenlines and kinematic indicators point to dextral strike-slip kinematics along this fault plane. Moreover, a series of lower order high-angle fault planes, with kinematic indicators pointing to oblique-slip to dip-slip normal kinematics, defines a few meter-wide negative flower structure associated with the main strike-slip fault (supporting information Figure S5e).

\section{Discussion}

In the following section, we first discuss the stratigraphic evolution and the structural architecture of the Gediz supradetachment basin to propose an evolutionary model. Finally, we discuss the implications of our reconstruction for the exhumation history of the Central Menderes Massif and we highlight the important role of magmatism in controlling the tectonic evolution of supradetachment systems.

\subsection{Insights From Micropaleontological Data}

Our micropaleontological data provide additional constraints for the stratigraphy and the paleogeographic evolution of the Neogene extensional basins in SW Anatolia and especially for the Gediz Graben. Our findings represent the first report of Neogene marine deposits in the Gediz Graben (and in the entire Menderes Massif). Moreover, our biostratigraphic data provide a younger middle-late Miocene age for the formation of the Gediz Graben, compared to the early-middle Miocene ages proposed previously (Cohen et al., 1995; Emre, 1996; Koçyiğit et al., 1999; Öner \& Dilek, 2011; Purvis \& Robertson, 2005a, 2005b; Seyitoğlu et al., 2002; Yllmaz et al., 2000). This new age is in agreement with the interpretation of borehole data (Çiftçi \& Bozkurt, 2009a) and with constraints provided by detrital apatite fission-track data (Asti et al., 2018). The few tens of meters-thick limestone at the base of the Çaltilik Fm, as far as we could observe in the field, is preceded and followed exclusively by continental deposits, thus represents the record of a short-lived 


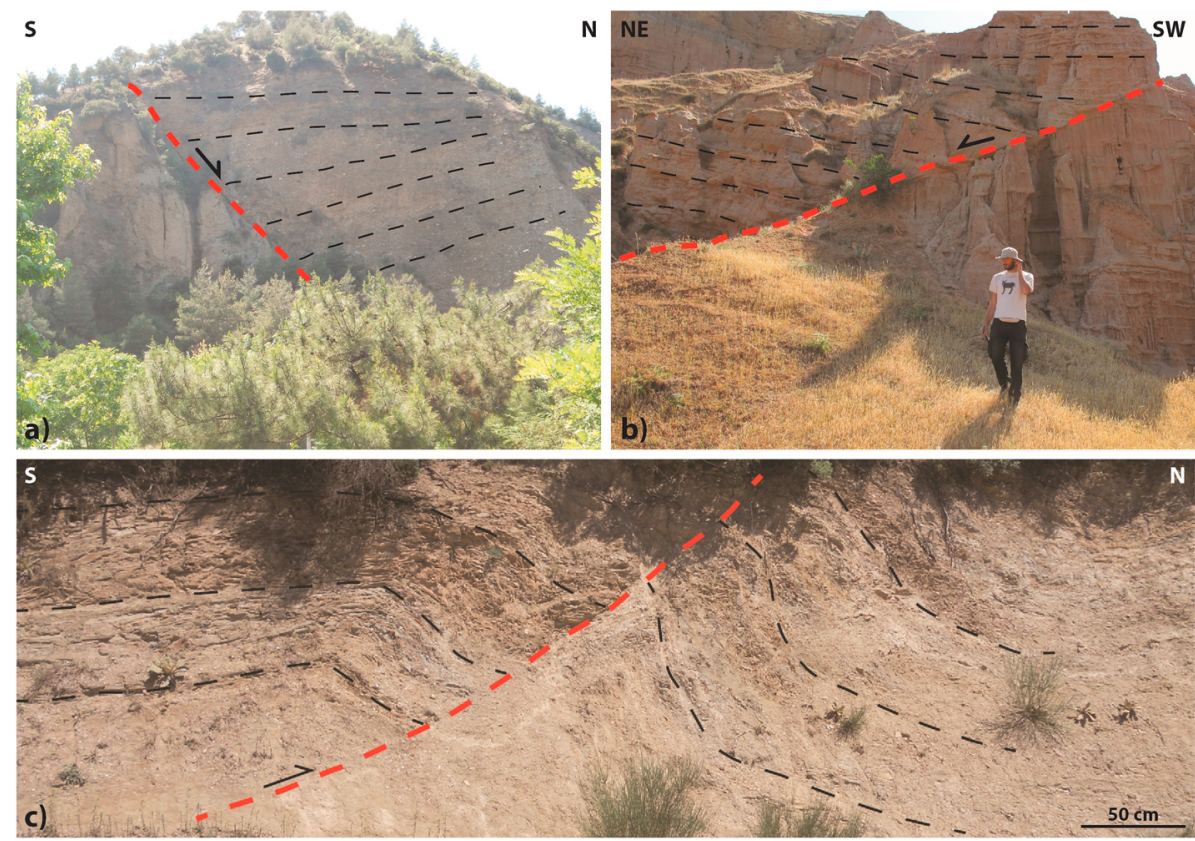

Figure 9. Examples of synsedimentary structures in the sedimentary fill of the basin. Growth strata in the Gediz Fm (a) and in the Çaltilik Fm (b); note the progressive tilting of the sedimentary bedding. Reverse fault in the Zeytinçayi Mbr of the Alaşehir Fm (c). See section 6.3 for further explanations.

marine episode in the evolution of the Gediz Graben. Since no major global eustatic event is reported for the upper Tortonian (e.g., Haq et al., 1987, 1988; Miller et al., 2005), this marine transgression is likely related to the local tectonic evolution of the basin. The end of this marine episode probably marks the boundary between an early phase of basin evolution, dominated by subsidence and increasing accommodation space, and a later phase dominated by a pronounced uplift of the southern basin margin, with consequently larger sedimentary flux that led to the definitive continentalization of the depositional setting (Asti et al., 2018).

Assuming a thickness of $\sim 1,000 \mathrm{~m}$ for the Çaltilik Fm, and integrating our micropaleontological results with paleontological data by Emre (1996), who assigned a Dacian age (Mio-Pliocene boundary) to the Göbekli Fm (that, in our interpretation based on field observation, can be correlated to the lower part of the Gediz Fm), we obtain a Messinian sedimentation rate of $\sim 500 \mathrm{~m} / \mathrm{Ma}$. This finding is in agreement with estimations based on apatite fission track data (Asti et al., 2018).

The sampled limestone deposit is presently located at an elevation of $\sim 760 \mathrm{~m}$ a.s.l. Assuming a bathymetry of $-100 \pm 50 \mathrm{~m}$ for its depositional environment, we could estimate a mean topographic uplift of $860 \pm 50 \mathrm{~m}$ for the southern margin of the basin in the Alaşehir area since the Late Tortonian, with a mean uplift rate of $107.5 \pm 6 \mathrm{~m} / \mathrm{Ma}$. However, because the basin underwent major subsidence and sedimentation after the deposition of these limestones, we infer that most of the topographic uplift occurred during the major Plio-Quaternary tectonic reorganization of the basin margin, which was associated with a much higher uplift rate.

\subsection{Control on the Distribution of the Neogene-to-Quaternary Basin Fill}

The exposure of the Neogene-to-Quaternary basin fill shows major differences between the Alaşehir and the Salihli areas. The older deposits (i.e., the Alaşehir Fm and the lower part of the Çaltilik Fm) are only exposed in the eastern sector, whereas the western sector includes exposures of the middle and upper part of the Çaltilik Fm and younger deposits (Figures 2 and 3). This configuration might be explained in two different ways. In the first hypothesis, the depositional setting was not homogeneous during the early stages of basin evolution, and therefore, some of the sediments were only deposited in the eastern part of the basin (e.g., Çiftçi \& Bozkurt, 2009a; Yılmaz et al., 2000; Çiftçi \& Bozkurt, 2010). Alternatively, the oldest deposits 
were deposited in the whole Gediz Graben area, but they are now buried beneath the younger units of the Salihli area. According to the latter scenario, the Alaşehir Fm and the limestone at the base of the Çaltilik Fm were possibly exposed in the past in the southernmost part of the Salihli area (as nowadays in the eastern sector), to be later eroded due to the differential uplift of the basement that was higher in this sector compared to the Alaşehir area in Plio-Quaternary times (Asti et al., 2018). We are in favor of the second scenario, which is supported by the structural relationship between the two sectors, with the ductile-to-brittle Gediz Detachment being exclusively exhumed in the Salihli area, and detrital apatite fission track data pointing to a younger exhumation event in the basement of the western sector (Asti et al., 2018).

\subsection{A Reappraisal of the Structural Architecture}

The low-angle fault surface at the southern margin of the basin in the Alaşehir area has been previously interpreted as the eastern equivalent of the Gediz Detachment (e.g., Çiftçi \& Bozkurt, 2009a; Seyitoğlu et al., 2015). In our interpretation this is unlikely, because this sector of the basin margin (and all the outcropping structures therein) lies in the hanging wall of the Gediz Detachment, as confirmed by apatite fission track data (Asti et al., 2018) and by the orientation of the surface of detachment and of the stretching lineation on it at the eastern termination of its outcropping area (i.e., western side of the Dereköy valley; Figure 2) where it plunges to the east below the Alasehir area. This means that the eastern part of the basin margin represents a higher crustal level with respect to the mylonitic detachment. This may explain the lack of a clear top-to-the-NE extensional ductile mylonitic fabric related to the Neogene extensional phase in the Alaşehir area.

The relationship between the detachment and the basin is not expected to change along strike before the localized Plio-Quaternary exhumation event, as the detachment preserves its NNE plunging at depth. The obliquity of the strike of the detachment with respect to the rift is only localized close to the Dereköy valley; to the east of this valley the detachment likely recovers its orientation parallel to the rift, similarly to what proposed by Brun and van den Driessche (1994) for gneiss domes (see their Figure 3). This is also consistent with images of the subsurface reconstructed by seismic reflection profiles which show the NE dipping Gediz Detachment at depth in the Alasehir area (see Çiftçi \& Bozkurt, 2008; Demircioğlu et al., 2010; Yılmaz \& Gelişli, 2003; Çiftçi \& Bozkurt, 2010).

The contractional structures (folds and reverse faults) observed in the Alaşehir Fm (see section 4.3.3 and Figure 4e) are interpreted as related to a N-S oriented compressional phase (e.g., Çiftçi \& Bozkurt, 2008), or as being extension related (Şengör \& Bozkurt, 2013). In our opinion, these apparently compressive structures may have formed in an extensional setting, possibly due to large-scale slumps in unconsolidated deposits. This hypothesis is supported by the fact that these structures are spatially and stratigraphically confined.

For what concerns the activity of MF1, field evidence points to a synsedimentary phase of activity for this structure during the deposition of the Çaltilik Fm and Gediz Fm. However, MF1 was likely active even after the deposition of these formations, because the slight increase of thickness of the strata does not fit with the large displacement accommodated by this structure (i.e., more than 1,000 m).

\subsection{Neogene-To-Present 2-D Evolution of the Gediz Detachment}

In order to quantify the amount of extension accommodated by the Gediz Detachment, we present a 2-D NESW reconstruction through the Salihli area in Figure 10. In agreement with previous interpretations (e.g., Buscher et al., 2013; Öner \& Dilek, 2011), we consider that the Gediz Detachment initiated with a dip angle similar to the present day one. For the sediment thicknesses used in this reconstruction, we integrate our field observations with well-log data and seismic reflection profiles interpretation (Çiftçi \& Bozkurt, 2009a, Çiftçi \& Bozkurt, 2010).

In our reconstruction the dip angle of the Gediz Detachment is constant through time; hence, all the block rotations are confined to the hanging wall of the detachment. The brittle faults at the southern margin of the basin, which control most of the sedimentation, are rooted in the ductile detachment. These faults developed at high angle $\left(60^{\circ}-70^{\circ}\right)$ and then progressively rotated during their activity, thus bordering tilted blocks above the detachment surface. During extension (Figures 10a-10d), the lower part of the metamorphic basement in the hanging wall of the detachment is progressively thinned by ductile and/or cataclastic flow. Progressive hanging wall thinning during extension has been proposed in several evolutionary models for the exhumation of metamorphic core complexes (e.g., Bartley \& Wernicke, 1984; Cooper et al., 2010; 


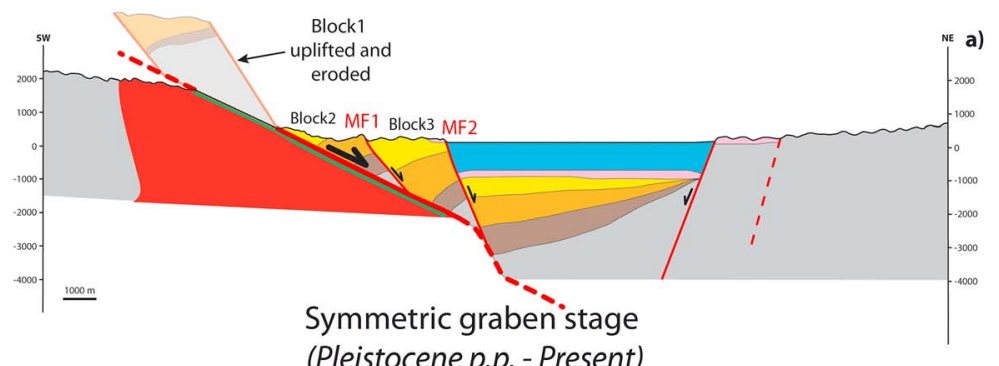

(Pleistocene p.p. - Present)
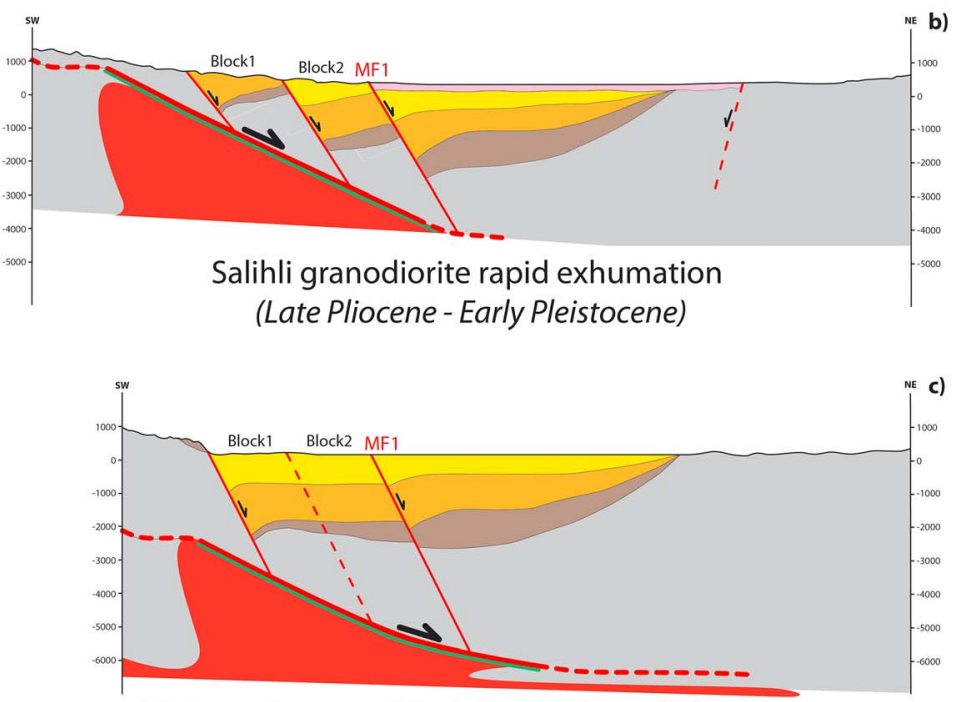

High-angle normal faults activation - Half-graben stage (Late Miocene-Early Pliocene)

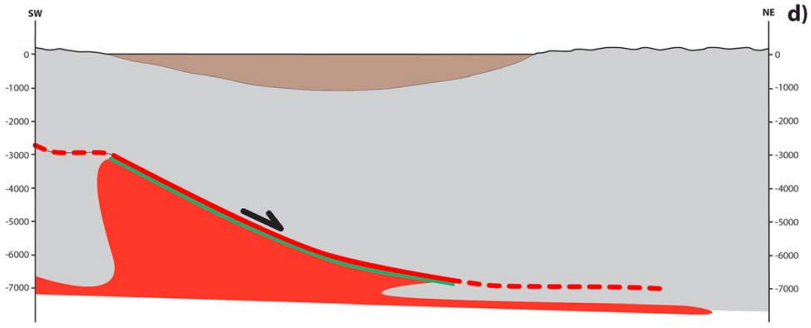

Activation of the Gediz Detachment - Ramp basin stage (Middle-Late Miocene)

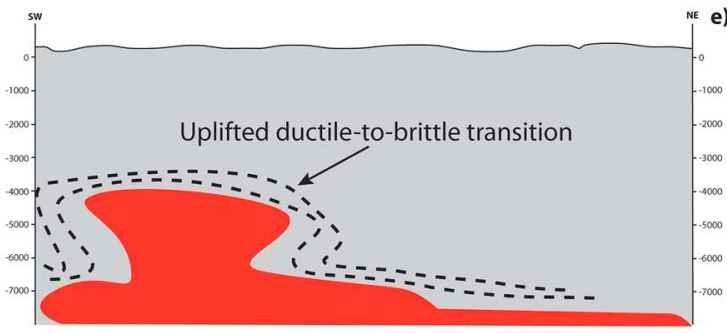

Upward migration of the ductile-to-brittle transition following the emplacement of Salihli granodiorite (Latest Early Miocene)

Figure 10. Two-dimensional across-strike reconstruction of the western part (Salihli area) of the study area, showing the Neogene-to-present evolution of this sector of the basin. During extension (a-d), the lower part of the metamorphic basement in the hanging wall of the detachment is progressively thinned by ductile and cataclastic flows (see text for further explanations). Block 1 is represented shaded in a) to show its possible position if not eroded. See text for further explanations. 
Lister \& Davis, 1989; Miller et al., 1983; Platt et al., 2015). Moreover, ductile flow has been documented as an important process assisting exhumation during crustal extension (e.g., Ring et al., 1999, and references therein). In the Gediz supradetachment system this process might have been favored by the high geothermal gradient induced by the emplacement of the Salihli granodiorite. In the last step of our reconstruction (Figure 10a), block 1 in the hanging wall of the detachment is uplifted more than the rest of the basin margin, and its uppermost portion is thus removed by erosion.

After the model restoration to the prestretching conditions, we obtained an intrusion depth for the Salihli Granodiorite between $\sim 3.5$ and $\sim 7 \mathrm{~km}$, which is in agreement with the thermobaric modeling of the emplacement conditions of the intrusion $(P<2$ kbar; Erkül et al., 2013; Rossetti et al., 2017). Our reconstruction suggests that the total amount of stretching accommodated by the Gediz Detachment and the faults in its hanging wall during their activity has been relatively small $(\sim 7.2 \mathrm{~km})$ during the last $\sim 15 \mathrm{Ma}$, producing the $\sim 3-\mathrm{km}$-deep and $\sim 20-\mathrm{km}$-wide Gediz Graben and exhuming the detachment itself. The amount of exhumation and the amount of horizontal extension are on the same order of magnitude. Exhumation was favored by activation and rotation of the high-angle normal faults in the hanging wall of the Gediz Detachment (see also Asti et al., 2018).

\subsection{Evolutionary Model}

By integrating our field observations and paleontological data with the wealth of published data on the Gediz Graben and on the Gediz Detachment, we have elaborated a five-stage Neogene-to-Present evolutionary model, schematically reported in Figure 11.

Stage 1 - The ductile deformation along the Gediz Detachment at shallow depths started around 14.6 Ma (Langhian), following the intrusion of the Salihli Granodiorite at 17 Ma (Burdigalian; Rossetti et al., 2017). It is likely that the formation of the basin and the deposition of the Alaşehir Fm started synchronously with the ductile activity of the detachment at depth (i.e., Langhian; Figure 11a), as suggested by detrital apatite fission track data (Asti et al., 2018) and volcanoclastic deposits found in boreholes (Çiftçi \& Bozkurt, 2009a). These findings are in contrast with an earlymiddle Miocene age as previously inferred from palynological data (Ediger et al., 1996; İztan \& Yazman, 1991; Seyitoğlu et al., 2002; Seyitoğlu \& Scott, 1992). Since the original relationship between the oldest deposits of the basin and its margins is not visible in outcrop, it is not easy to reconstruct the geometry of the basin at the time of its formation. The lack of growth strata toward the basin margins suggests that no major extensional faults were controlling the development of the basin during sedimentation of the Alaşehir Fm. This might suggest that the sedimentation started in a ramp basin setting (i.e., a sag-like depression) possibly reflecting the flat-ramp geometry of the Gediz Detachment at depth (e.g., Fillmore et al., 1994; Gibbs, 1984; Vetti \& Fossen, 2012). Notably, no major exhumation event is evidenced during this phase by apatite fission track data (Asti et al., 2018).

Stage 2 - The subsidence-dominated phase terminates with the upper Tortonian short-lived marine episode represented by the limestone at the base of the Çaltilik Fm (Figure 11b). During this phase, the onset of a relatively shallow (50-150-m) marine environment is testified by the faunal assemblage described in this study.

Stage 3 - Starting from the Messinian, the Gediz Graben experienced a major tectonosedimentary reorganization (Figure 11c). During this phase, a high-angle brittle normal fault system was activated at the southern margin of the basin, shaping the basin as a half-graben and controlling the sedimentation of the Çaltilik Fm during the Messinian and of the Gediz Fm during the (Early?) Pliocene, which are both thickened toward the southern margin. This tectonic phase is also linked to a relevant exhumation pulse at the southern margin of the basin, with associated detritus influx toward the basin (Asti et al., 2018), which led to its definitive continentalization.

Stage 4 - During the (Late?) Pliocene-(Early?) Pleistocene, the normal fault-bounded tectonic wedges located between the Gediz Detachment and the MF1 started being exhumed in the footwall of this latter structure, leading to the recycling of parts of the previously deposited sedimentary sequence (Figure 11d); the strongest evidence for such recycling is the occurrence, in the conglomeratic levels of the Kaletepe Fm, of pebbles of sedimentary rocks, contrasting with the older formations that were exclusively constituted by metamorphic rocks. Interpretation of seismic 

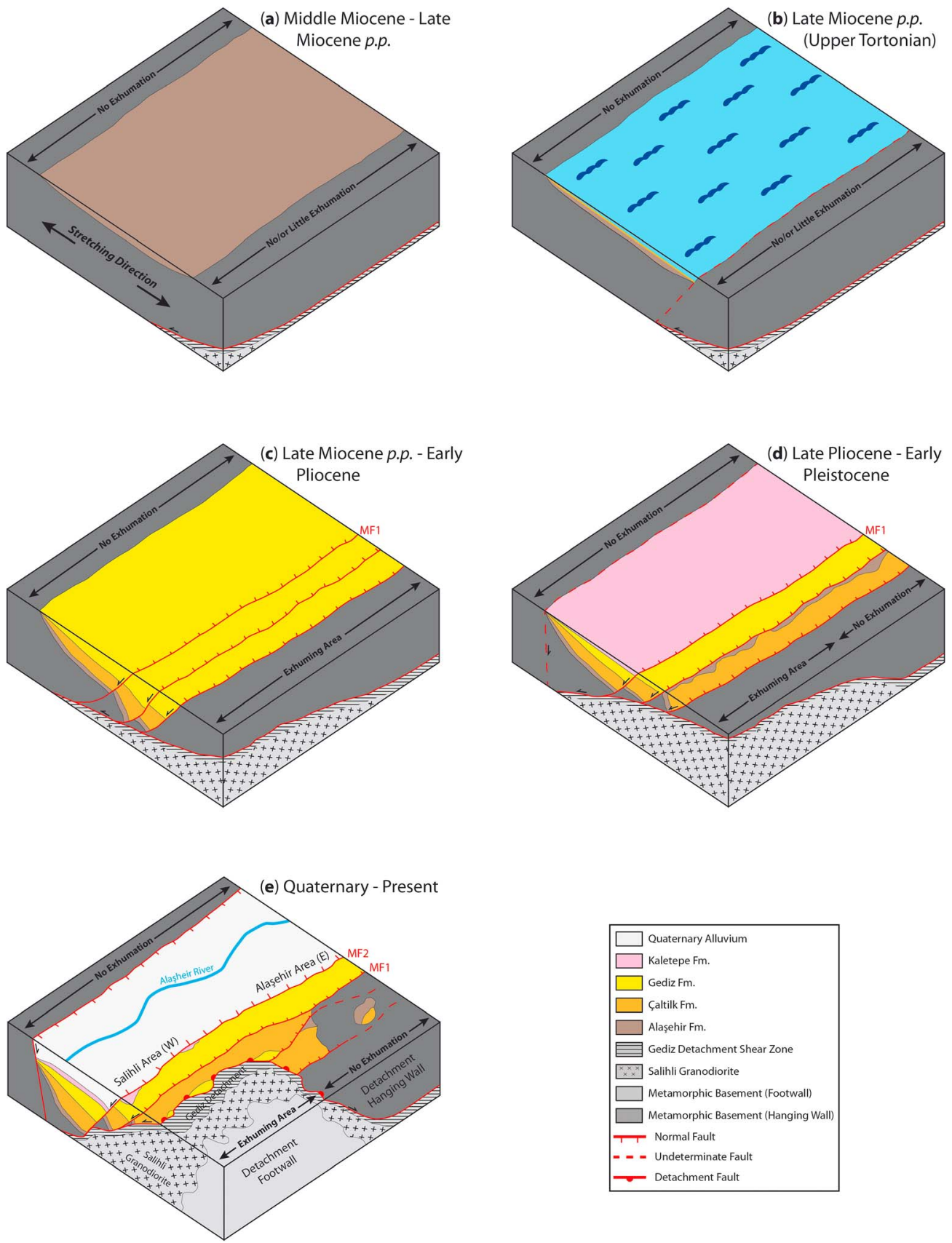

Figure 11. Block diagrams schematically showing the main sedimentary and tectonic events in the evolution of the Gediz Graben. Please note that for the sake of simplicity the basin is represented as a single trough since its early stages, even if an early segmentation in two/three different subbasins is possible (see Çiftçi \& Bozkurt, 2010). (a) Middle Miocene-late Miocene p.p.: deposition of the Alaşehir Fm in a ramp basin contemporaneously with the activation of the ductile deformation on the Gediz Detachment at depth; no major exhumation of the basin margins occurs during this period. (b) Late Miocene p.p. (upper Tortonian): marine transgression in the Gediz Graben and deposition of the limestone at the base of the Çaltilik Fm. (c) Late Miocene p.p.-early Pliocene: activation of major brittle faults bounding the southern margin of the basin and controlling the sedimentation of the Çaltilik Fm and Gediz Fm in an half-graben setting; in this phase the entire southern margin of the basin underwent relevant exhumation. (d) Late Pliocene (?)-Early Quaternary: deposition of the unconformable Kaletepe Fm and activation of the norther margin of the basin; during this phase the oldest portions of the sedimentary fill are tilted and exposed at the surface and the Salihli Granodiorite and the Gediz Detachment are moving towards the surface in the western part of the graben. (e) Quaternary to present: activation of the MF2 fault and formation of the present-day Gediz Graben alluvial plain; during this phase the oldest sedimentary units previously exposed along the southern margin are more uplifted in the western part than in the eastern part and then eroded in the former sector, thus leading to the present-day pattern of the distribution of the ancient sedimentary fill in outcrop. 
reflection profiles suggests that the northern margin of the basin was activated at this time, shaping the geometry of the basin from a half-graben toward a symmetric graben (Çiftçi \& Bozkurt, 2009a; Çiftçi \& Bozkurt, 2010).

Stage 5 - The last exhumation event involved only the southwestern sector of the study area, bringing the Gediz Detachment and its footwall, including the Salihli Granodiorite, to the surface (Figure 11e). This event is registered by fission track data (Asti et al., 2018; Buscher et al., 2013; Gessner et al., 2001 ; Ring et al., 2003), which reveal along-strike variations in short-term erosion rates at the southern margin of the graben. This last and localized exhumation event likely generated a recent uplift of the southwestern portion of the margin, thus uplifting the older portion of the sedimentary fill exposed in this sector and facilitating its erosional removal (Asti et al., 2018). In this period, fault MF2 was likely activated together with the northern margin bounding fault, controlling the formation of the present-day alluvial plain and the physiography of the symmetric graben.

\subsection{Control of Magmatism on the Exhumation Pattern Along Detachment Systems}

The proposed tectonic reconstruction has major implications for the evolution and exhumation of the Central Menderes Massif. In particular, the late Miocene or younger exhumation events are localized at the southern margin of the Gediz Graben. The same scenario of localized exhumation likely applies to the northern margin of the Büyük Menderes Graben (see contour map of the bedrock apatite fission track ages in Gessner et al., 2013, their Figure 8). Moreover, some older (early-middle Miocene) bedrock apatite fission track ages are observed in the inner part of the central submassif (Gessner et al., 2001; Ring et al., 2003). This suggests that the Central Menderes Massif was exhumed to the surface more or less at the same time of the rest of the Menderes Massif and during the same major exhumation event that took place in the latest Oligocene-Middle Miocene. Only its northern and southern margins underwent major exhumation since the latest Middle Miocene, although with relevant along-strike variations (Asti et al., 2018; Gessner et al., 2001; Ring et al., 2003). This evidence rules out a younger unroofing phase of the whole central submassif relative to the rest of the Menderes Massif. Moreover, the most recent exhumation event recorded at the northern margin of the Central Menderes Massif was localized in the intrusion area of the Salihli and Turgutlu granodiorites, thus suggesting that these intrusions may have played a role not only in triggering the ductile-to-brittle detachment tectonics in this area (Rossetti et al., 2017), but also in controlling the exhumation pattern, although the precise mechanism is still unclear.

Numerical models have shown that the topographic evolution of a region where a magmatic intrusion emplaces in less dense sediments results (counterintuitively) in a positive relief of the area above the intrusion, which also shows a higher exhumation rate compared to the host rock (Braun et al., 2014). However, these conditions are not matched in our study area. As a matter of fact, the Salihli and Turgutlu granodiorites emplaced in the metamorphic basement of the Menderes Massif, which is mainly composed by greenschist to amphibolite facies metasediments and orthogneisses (Ring, 2001; Ring, Gessner, et al., 1999). Thus, the density contrast between the intrusion(s) and the host rocks should be null or inverse with respect to the case presented by Braun et al. (2014). We may thus envisage some possible effect of buoyancy of the granodioritic intrusions as a result of their lower density or of their higher temperature with respect to their host rocks.

Another possibility to explain the localization of the Plio-Quaternary exhumation event deals with the evolution of faulting at the southern margin of the basin. Kent et al. $(2016,2017)$ showed that active fault segments bounding the southern margin of the modern Gediz Graben became connected during the last 2.6$2 \mathrm{Myr}$, thus resulting in an increase in throw rates along the Salihli segment of this fault system. This increase in throw rate might have also played a role in the differential exhumation of the Gediz detachment in the Salihli area. However, it is difficult to explain the pattern of the foliation and of the stretching lineation on the Gediz detachment surface (which seems related also to its exhumation history) simply invoking the dynamics of recent faulting as controlling mechanism for its differential exhumation.

More work is needed to properly characterize the evolution of recent faulting and its possible interactions with the exhumation pattern. More, in general, even though prekinematic to synkinematic intrusions are often documented in extensional detachment systems worldwide and usually result in topographic highs, the importance of their differential exhumation history in controlling the structural and stratigraphic 
evolution of supradetachment systems (as demonstrated in this study) is not yet studied elsewhere and opens new prospective in the comprehension of the evolution of highly extended terrains.

\subsection{Insights on the Development of Extensional Detachment Tectonics in the Aegean Region}

The Aegean and Menderes case studies show that a close relationship exists between magmatic intrusions and localization of ductile-to-brittle detachment tectonics at shallow crustal depths during regional-scale approximately N-S stretching in the Neogene (e.g., Brichau et al., 2007; Denèle et al., 2011; Duchêne et al., 2006; Jolivet \& Brun, 2010; Laurent et al., 2015; Rossetti et al., 2017; Seward et al., 2009). This evidence suggests that magma underplating and emplacement likely favored a transient rheological weakening of the upper crust, generating the conditions for the localization of ductile extensional shearing on shallow detachment faults (e.g., Caggianelli et al., 2013; Lister \& Baldwin, 1993; Rossetti et al., 2017). The large amount of extension cumulated in the whole Aegean realm since Eocene in the back arc of the Hellenic subduction system might have been then facilitated by the widespread and polyphase magmatic activity that repeatedly assisted the localization of deformation in different domains of the Aegean back arc. The Menderes Massif, analogously to the Corinth Gulf to the west, represents the eastern lateral termination of the Aegean extensional province. Here the total horizontal extension is smaller than in the central Aegean domain and preextensional/synextensional magmatism is less distributed than in the rest of the Aegean. This further supports the idea that a positive feedback exists between widespread synextensional magmatism and the amount of cumulated regional horizontal stretching in the extending crust.

Another important implication derived from the study of the tectonostratigraphic evolution of the Gediz Graben concerns the amount of exhumation and stretching accommodated in the upper crust by detachment faulting during Aegean extension. In particular, the close time-space association between enhanced exhumation, basin subsidence, and pluton emplacement in the extending crust suggests that ductile-tobrittle detachment faults might have been responsible only for the local exhumation of plutons emplaced at shallow depths rather than having accommodated whole crustal stretching. The cause of the differential evolution of the source areas induced by magmatic emplacement remains unclear, and its feedbacks with the stratigraphic record in supradetachment systems are poorly studied in other continental detachment systems worldwide. In this sense, this study opens new perspectives for the comprehension of the tectonic evolution of highly extended terranes.

\section{Conclusion}

The main conclusions of this work can be summarized as follows:

- An upper Tortonian marine episode has been identified in the Neogene stratigraphic succession of the Gediz Graben. The limestone at the base of the Çaltilik Fm hosts a shallow marine faunal assemblage, paleontologically dated between 8.35 and 7.25 Ma. This finding represents the first report for a Neogene marine episode in the entire Menderes Massif area and constrains the onset of the basin to Middle Miocene. This finding also provides a firm temporal constraint to evaluate the post-Miocene regional uplift rate.

- The lower part of the stratigraphic succession (i.e., the Alaşehir Fm and the lower part of the Çaltilik Fm) was likely deposited in the entire Gediz Graben, in a approximately E-W trending basin, rather than only in its eastern sector. In the western part of the basin, these deposits would now be buried below the younger formations in the more internal part of the basin, whereas they were probably uplifted and eroded in the southerly part.

- The Gediz Graben displayed many different geometries during its extensional evolution, starting in the Middle Miocene as a ramp basin, passing to half-graben geometry with an active southern margin during the late Miocene and ending as a symmetric graben since the (Late Pliocene? -) Quaternary activation of the northern margin. Since no major interruption of the sedimentation has been identified in the Neogene-to-Quaternary stratigraphic sequence, it is likely that this evolution developed as a continuous process without major interruptions.

- Field evidence has confirmed the structural relationship between the western and the eastern sector of the southern margin of the basin: the former is represented by the Gediz Detachment and its footwall (including the Salihli Granodiorite), whereas the latter is represented by the metamorphic bedrock in the hanging wall of the detachment, thus representing an higher and less exhumed crustal level. This 
geometry implies that the Gediz Detachment does not bound the entire southern margin of the Gediz Graben along its strike but is rather exhumed only in the western sector of the basin, where the preextensional Salihli and Turgutlu Granodiorites intruded its footwall.

- No major rotation of the gently dipping Gediz Detachment occurred since the beginning of its activity in the middle Miocene. The amount of extension accommodated by this structure and by the high-angle brittle faults since the early formation of the Gediz Graben is relatively small (i.e., less than $10 \mathrm{~km}$ since the middle Miocene). This implies that relatively small amounts of extension might be required on a lowangle detachment system to exhume shallow (i.e., less than $7 \mathrm{~km}$ of depth) preextension magmatic intrusions.

- It is likely that the Central Menderes Massif was already exhumed during the main Menderes cooling event in the latest Oligocene-Middle Miocene times. Accordingly, the younger exhumation events were localized on and involved only its northern and southern margins in the footwall of the structures bounding the Gediz Graben and the Büyük Menderes Graben.

- The youngest late Pliocene-early Pleistocene exhumation event that led the ductile-to-brittle Gediz Detachment to the surface was extremely localized at the exposure area of the Salihli and Turgutlu granodiorites, thus suggesting that the presence of these intrusions might have somehow controlled the exhumation patterns.

In general, our data allowed us to propose an evolutionary model for the tectonostratigraphic history of supradetachment basins, where sedimentary rocks originally deposited in the hanging wall of detachment faults are eventually put in tectonic contact with the mylonitic footwall. Moreover, this study suggests a fundamental role of magmatism in controlling the tectonostratigraphic evolution and the exhumation history of highly extended terrains: after controlling the activation and the localization of ductile-to-brittle extensional detachment tectonics (even at shallow crustal depths), magmatic intrusions may also generate a complex exhumation pattern along detachment systems, thus influencing the tectonostratigraphic evolution of the associated sedimentary systems.

\section{Appendix: Biostratigraphy and Environmental Occurrence of P. kollmanni A.}

P. kollmanni is an extinct Mediterranean marine species found in France, Austria, Italy, and Crete. It has been named by Carbonnel (1966) who first found it in Tortonian marine infralittoral deposits of the Rhone Basin (France). Ascoli (1968) found this species in the Tortonian type-section of Rio Mazzapiedi (Italy) in association with other circalittoral species. Sissingh (1972) found P. kollmanni in the Apostoli Section (Crete), in deposits attributed to an infralittoral to circalittoral environment and suggested that this species may be confined in the Cytherella vandenboldi Zone, corresponding to the Middle Tortonian chronostratigraphic interval. Dall'Antonia and Bossio (2001) reported its occurrence in marine shelf deposits from the uppermost Langhian to the Serravallian in the Salentine Peninsula (Italy). Finally, Gebhardt et al. (2009) found this species in association with other circalittoral species in deposits of the Austrian Molasse Basin, attributed to the lower Badenian (corresponding to the upper Langhian).

Acknowledgments

The research that our team at Roma TRE is pursuing in the Mediterranean flourished from the extraordinary and creative mind of Renato Funiciello. His holistic view to Earth Science unselfishly guided generations of scholars on geophysics, geology, and volcanology. C. F. and F. R. wish to express their gratitude to Renato Funiciello for his continuous and generous support. The manuscript benefitted from insightful comments and reviews by L. Joliver (Editor), D. Gürer, P. T. Osmundsen, and an anonymous reviewer. S. Özden, O.H. Gögüus, A. Yangöz, S.C. Ülgen, and N. Öğretmen are kindly acknowledged for their field assistance. Supported by MIUR-Italy Dipartimenti di Eccellenza grant. All data presented in this manuscript are presented in sections 4-6 or are properly cited and referred to in the reference list.

\section{References}

Ascoli, P. (1968). Preliminary report on the Ostracoda of the type-Tortonian. Giornale di Geologia, 35(2), 31-51.

Asti, R., Malusà, M. G., \& Faccenna, C. (2018). Supradetachment basin evolution unravelled by detrital apatite fission track analysis: The Gediz Graben (Menderes Massif, Western Turkey). Basin Research, 30(3), 502-521. https://doi.org/10.1111/bre.12262

Bargnesi, E. A., Stockli, D. F., Mancktelow, N., \& Soukis, K. (2013). Miocene core complex development and coeval supradetachment basin evolution of Paros, Greece, insights from (U-Th)/He thermochronometry. Tectonophysics, 595-596, 165-182. https://doi.org/10.1016/j. tecto.2012.07.015

Bartley, J. M., \& Wernicke, B. P. (1984). The Snake Range décollement interpreted as a major extensional shear zone. Tectonics, 3(6), 647-657. https://doi.org/10.1029/TC003i006p00647

Bozkurt, E., \& Oberhänsli, R. (2001). Menderes Massif (Western Turkey): Structural, metamorphic and magmatic evolution-A synthesis. International Journal of Earth Sciences (Geologische Rundschau), 89(4), 679-708. https://doi.org/10.1007/s005310000173

Bozkurt, E., \& Park, G. R. (1994). Southern Menderes massif: An incipient metamorphic core complex in western Anatolia, Turkey. Journal of the Geological Society of London, 151(2), 213-216. https://doi.org/10.1144/gsjgs.151.2.0213

Bozkurt, E., \& Sözbilir, H. (2004). Tectonic evolution of the Gediz Graben: Field evidence for an episodic, two-stage extension in western Turkey. Geological Magazine, 141(1), 63-79. https://doi.org/10.1017/S0016756803008379

Braun, J., Simon-Labric, T., Murray, K. E., \& Reiners, P. W. (2014). Topographic relief driven by variations in surface rock density. Nature Geoscience, 7(7), 534-540. https://doi.org/10.1038/NGEO2171 
Brichau, S., Ring, U., Carter, A., Monié, P., Bolhar, R., \& Stockli, D. (2007). Extensional faulting on Tinos Island, Aegean Sea, Greece: How many detachments? Tectonics, 26, TC4009. https://doi.org/10.1029/2006TC001969

Brun, J. P., \& Sokoutis, D. (2007). Kinematics of the Southern Rhodope Core Complex (North Greece). International Journal of Earth Sciences, 96(6), 1079-1099. https://doi.org/10.1007/s00531-007-0174-2

Brun, J.-P., \& van den Driessche, J. (1994). Extensional gneiss domes and detachment fault systems-Structure and kinematics. Bulletin de la Societe Geologique de France, 165, 519-530.

Burg, J. P. (2011). Rhodope: From Mesozoic convergence to Cenozoic extension. Review of petro-structural data in the geochronological frame. Journal of the Virtual Explorer, 42.

Buscher, J. T., Hampel, A., Hetzel, R., Dunk, L. I., Glotzbach, C., Struffert, A., et al. (2013). Quantifying rates of detachment faulting and erosion in the central Menderes massif (western Turkey) by thermochronology and cosmogenic 10Be. Journal of the Geological Society of London, 170(4), 669-683. https://doi.org/10.1144/jgs2012-132

Caggianelli, A., Ranalli, G., Lavecchia, A., Liotta, D., \& Dini, A. (2013). Post-emplacement thermo-rheological history of a granite intrusion and surrounding rocks: The Monte Capanne pluton, Elba Island, Italy. Geological Society, London, Special Publications, 394(1), 129-143. https://doi.org/10.1144/SP394.1

Carbonnel, G. (1966). Essai d'étude statistique à propos d'un nouveau genre d'Ostracode Pseudopsammocythere. Revue de Micropaléont, 9(1), 50-54. 4 text-figs., 1 pl., Paris

Catlos, E. J., Baker, C., Sorensen, S. S., Çemen, I., \& Hancer, M. (2010). Geochemistry, geochronology, and cathodoluminescence imagery of the Salihli and Turgutlu granites (central Menderes Massif, western Turkey): Implications for Aegean tectonics. Tectonophysics, 48, $110-130$.

Catlos, E. J., Baker, C. B., Sorensen, S. S., Jacob, L., \& Çemen, I. (2011). Linking microcracks and mineral zoning of detachment-exhumed granites to their tectonomagmatic history: Evidence fromthe Salihli and Turgutlu plutons in western Turkey (Menderes Massif). Journal of Structural Geology, 33(5), 951-969. https://doi.org/10.1016/j.jsg.2011.02.005

Catlos, E. J., \& Çemen, I. (2005). Monazite ages and the evolution of the Menderes Massif. International Journal of Earth Sciences, 94(2), 204-217. https://doi.org/10.1007/s00531-005-0470-7

Çemen, İ., Tekeli, O., Seyitoğlu, G., \& Işık, V. (2005). Are turtleback fault surfaces common structural elements of highly extended terranes? Earth Science Reviews, 73(1-4), 139-148. https://doi.org/10.1016/j.earscirev.2005.07.001

Çiftçi, N. B., \& Bozkurt, E. (2008). Folding of the Gediz Graben fill, SW Turkey: Extensional and/or contractional origin? Geodinamica Acta, 21(3), 145-167. https://doi.org/10.3166/ga.21.145-167

Çiftçi, N. B., \& Bozkurt, E. (2009a). Evolution of the Miocene sedimentary fill of the Gediz Graben, SW Turkey. Sedimentary Geology, 216(3-4), 49-79. https://doi.org/10.1016/j.sedgeo.2009.01.004

Çiftçi, N. B., \& Bozkurt, E. (2009b). Pattern of normal faulting in the Gediz Graben, SW Turkey. Tectonophysics, 473(1-2), 234-260. https://doi.org/10.1016/j.tecto.2008.05.036

Çiftçi, N. B., \& Bozkurt, E. (2010). Structural evolution of the Gediz Graben, SW Turkey: Temporal and spatial variation of the graben basin. Basin Research, 22, 846-873.

Cohen, H. A., Dart, C. J., Akyüz, H. S., \& Barka, A. A. (1995). Syn-rift sedimentation and structural development of Gediz and Büyük Menderes graben, western Turkey. Journal of the Geological Society, London, 152(4), 629-638. https://doi.org/10.1144/ gsjgs.152.4.0629

Cooper, F. J., Platt, J. P., Anczkiewicz, R., \& Whitehouse, M. J. (2010). Footwall dip of a core complex detachment fault: Thermobarometric constraints from the northern Snake Range (Basin and Range, USA). Journal of Metamorphic Geology, 28(9), 997-1020. https://doi.org/ 10.1111/j.1525-1314.2010.00907.x

Crittenden, M. D. Jr., Coney, P. J., \& Davis, G. H. (1980). Metamorphic core complexes of the North American Cordillera: Summary. Geological Society of America Memoirs, 153. https://doi.org/10.1130/MEM153-p485

Dall'Antonia, B., \& Bossio, A. (2001). Middle Miocene ostracods from the Salentine peninsula. Rivista Italiana di Paleontologia e Stratigrafia, 107(3), 395-424.

Davis, G. A., \& Friedmann, S. J. (2005). Large-scale gravity sliding in the Miocene Shadow Valley Supradetachment Basin, Eastern Mojave Desert, California. Earth-Science Reviews, 73(1-4), 149-176. https://doi.org/10.1016/j.earscirev.2005.04.008

Davis, G. H., Constenius, K. N., Dickinson, W. R., Rodríguez, E. P., \& Cox, L. J. (2004). Fault and fault-rock characteristics associated with Cenozoic extension and core-complex evolution in the Catalina-Rincon region, southeastern Arizona. Geological Society of America Bulletin, 116(1), 128-141. https://doi.org/10.1130/B25260.1

Demircioğlu, D., Ecevitoğlu, B., \& Seyitoğlu, G. (2010). Evidence of a rolling hinge mechanism in the seismic records of hydrocarbonbearing Alaşehir graben, western Turkey. Petroleum Geoscience, 16(2), 155-160. https://doi.org/10.1144/1354-079309-017

Denèle, Y., Lecomte, E., Jolivet, L., Lacombe, O., Labrousse, L., Huet, B., \& Le Pourhiet, L. (2011). Granite intrusion in a metamorphic core complex: The example of the Mykonos laccolith (Cyclades, Greece). Tectonophysics, 501(1-4), 52-70. https://doi.org/10.1016/j. tecto.2011.01.013

Dinter, D. A. (1998). Late Cenozoic extension of the Alpine collisional orogen, northeastern Greece: Origin of the north Aegean basin Geological Society of America Bulletin, 110(9), 1208-1230. https://doi.org/10.1130/0016-7606(1998)110<1208:LCEOTA>2.3.CO;2

Duchêne, S., Aïssa, R., \& Vanderhaeghe, O. (2006). Pressure-temperature time evolution of metamorphic rocks from Naxos (Cyclades, Greece): Constraints from thermobarometry and Rb/Sr dating. Geodinamica Acta, 19(5), 301-321. https://doi.org/10.3166/ga.19.301-321

Ediger, V. Ş., Batı, Z., \& Yazman, M. (1996). Paleopalynology of possible hydrocarbon source rocks of the Alaşehir-Turgutlu area in the Gediz Graben (western Anatolia). Turkish Association of Petroleum Geologists, 8, 94-112.

Emre, T. (1996). Geology and tectonics of Gediz Graben. Turkish Journal of Earth Sciences, 5, 171-185.

Erkül, F., Erkül, S. T., Ersoy, Y., Uysal, I., \& Krötzli, U. (2013). Petrology, mineral chemistry and Sr-Nd-Pb isotopic compositions of granitoids in the central Menderes metamorphic core complex: Constraints on the evolution of Aegean lithosphere slab. Lithos, 180-181, 74-91. https://doi.org/10.1016/j.lithos.2013.07.022

Ersoy, E. Y., Helvac1, C., \& Palmer, M. R. (2011). Stratigraphic, structural and geochemical features of the NE-SW-trending Neogene volcano-sedimentary basins in western Anatolia: Implications for associations of supradetachment and transtensional strike-slip basin formation in extensional tectonic setting. Journal of Asian Earth Sciences, 41(2), 159-183. https://doi.org/10.1016/j. jseaes.2010.12.012

Fillmore, R. P., \& Walker, J. D. (1996). Evolution of a supradetachment extensional basin: The Lower Miocene Pickhandle basin, central Mojave Desert, California. Special Papers-Geological Society Of America, 303, 107-126.

Fillmore, R. P. (1993). Sedimentation and extensional basin evolution in a Miocenemetamorphic core complex setting, Alvord Mountain, central Mojave Desert, U.S.A. Sedimentology, 40, 721-742. 
Fillmore, R. P., Walker, J. D., Bartley, J. M., \& Glazner, A. F. (1994). Development of three genetically related basins associated with detachment-style faulting: Predicted characteristics and an example from the central Mojave Desert, California. Geology, 22(12), 1087-1090. https://doi.org/10.1130/0091-7613(1994)0222.3.CO;2

Friedmann, S. J., \& Burbank, D. W. (1995). Rift basins and supradetachment basins: Intracontinental extensional end-members. Basin Research, 7(2), 109-127. https://doi.org/10.1111/j.1365-2117.1995.tb00099.x

Gautier, P., Brun, J.-P., Moriceau, R., Sokoutis, D., \& Martinod, J. L. J. (1999). Timing, kinematics and cause of Aegean extension: A scenario based on a comparison with simple analogue experiments. Tectonophysics, 315(1-4), 31-72. https://doi.org/10.1016/S00401951(99)00281-4

Gebhardt, H., Zorn, I., \& Roetzel, R. (2009). The initial phase of the Early Sarmatian (Middle Miocene) transgression. Foraminiferal and ostracod assemblages from an incised valley fill in the Molasse Basin of Lower Austria. Australian Journal of Earth Sciences, 102(2), 100-119.

Gessner, K., Gallardo, L. A., Markwitz, V., Ring, U., \& Thomson, S. N. (2013). What caused the denudation of the Menderes Massif: Review of crustal evolution, lithosphere structure, and dynamic topography in southwest Turkey. Gondwana Research, 24(1), 243-274. https:// doi.org/10.1016/j.gr.2013.01.005

Gessner, K., Ring, U., Johnson, C., Hetzel, R., Passchier, C. W., \& Gungor, T. (2001). An active bivergent rolling-hinge detachment system: Central Menderes metamorphic core complex in western Turkey. Geology, 29(7), 611-614. https://doi.org/10.1130/00917613(2001)029<0611:AABRHD>2.0.CO;2

Gibbs, A. D. (1984). Structural evolution of extensional basin margins. Journal of the Geological Society of London, 141(4), 609-620. https://doi.org/10.1144/gsjgs.141.4.0609

Glodny, J., \& Hetzel, R. (2007). Precise U-Pb ages of syn-extensional Miocene intrusions in the central Menderes Massif, western Turkey. Geological Magazine, 144(02), 235-246. https://doi.org/10.1017/S0016756806003025

Haq, B. U., Hardenbol, J., \& Vail, P. R. (1988). Mesozoic and Cenozoic chronostratigraphy and cycles of sea-level change. In C. K. Wilgus, B. S. Hastings, C. G. S. C. Kendall, H. W. Posamentier, C. A. Ross, \& J. C. van Wagoner (Eds.), Sea level changes-An integrated approach: SEPM, Special Publication (Vol. 42, pp. 72-108). Broken Arrow, OK: SEPM (Society of Economic Paleontologists and Mineralogists) https://doi.org/10.2110/pec.88.01.0071

Haq, B. U., Hardenbol, J., \& Vail, P. R. (1987). Chronology of fluctuating sea levels since the Triassic (250 million years ago to present). Science, 235(4793), 1156-1167. https://doi.org/10.1126/science.235.4793.1156

Hetzel, R., Passchier, C. W., Ring, U., \& Dora, O. Ö. (1995). Bivergent extension in orogenic belts; the Menderes Massif (southwestern Turkey). Geology, 23(5), 455-458. https://doi.org/10.1130/0091-7613(1995)023<0455:BEIOBT>2.3.CO;2

Hetzel, R., \& Reischmann, T. (1996). Intrusion age of Pan-African augen gneisses in the southern Menderes massif and the age of cooling after Alpine ductile extensional deformation. Geological Magazine, 133(05), 565-572. https://doi.org/10.1017/S0016756800007846

Hetzel, R., Ring, U., Akal, C., \& Troesch, M. (1995). Miocene NNE-directed extensional unroofing in the Menderes Massif, southwestern Turkey. Journal of the Geological Society of London, 152(4), 639-654. https://doi.org/10.1144/gsjgs.152.4.0639

Hinsbergen, D. J. J., Dekkers, M. J., Bozkurt, E., \& Koopman, M. (2010). Exhumation with a twist: Paleomagnetic constraints on the evolution of the Menderes metamorphic core complex, western Turkey. Tectonics, 29, TC3009. https://doi.org/10.1029/ 2009TC002596

Hinsbergen, D. J. J., \& Meulenkamp, J. E. (2006). Neogene supradetachment basin development on Crete (Greece) during exhumation of the South Aegean core complex. Basin Research, 18(1), 103-124. https://doi.org/10.1111/j.1365-2117.2005.00282.x

Iaccarino, S. M., Premoli, S. I., Biolz, M., Foresi, L. M., Lirer, F., Urco, E., \& Petrizzo, M. R. (2007). Practical manual of Neogene planktonic foraminifera. In VI Course (February 19-23): Neogene-Perugia (Chap. 5, p. 181). Italy: International School on Planktonic Foraminifera.

Işik, V., Seyitoğlu, G., \& Çemen, I. (2003). Ductile-brittle transition along the Alaşehir detachment fault and its structural relationship with the Simav detachment fault, Menderes massif, western Turkey. Tectonophysics, 374(1-2), 1-18. https://doi.org/10.1016/S00401951(03)00275-0

Isik, V., \& Tekeli, O. (2001). Structure of lower plate rocks in metamorphic core complex: Northern Menderes Massif, Western Turkey. International Journal of Earth Sciences, 89, 757-765.

İztan, H., \&Yazman, M. (1991). Geology and hydrocarbon potential of the Alaşehir (Manisa) area, western Turkey. Proceedings of the International Earth Sciences Congress on Aegean Regions, Izmir, 327-338.

Janecke, S. U., McIntosh, W., \& Good, S. (1999). Testing models of rift basins: Structure and stratigraphy of a Eocene-Oligocene supradetachment basin, Muddy Creek half graben, southwest Montana. Basin Research, 12, 143-167.

Jolivet, L., \& Brun, J. P. (2010). Cenozoic geodynamic evolution of the Aegean. International Journal of Earth Sciences, 99(1), 109-138. https://doi.org/10.1007/s00531-008-0366-4

Jolivet, L., \& Faccenna, C. (2000). Mediterranean extension and the Africa-Eurasia collision. Tectonics, 19(6), 1095-1106. https://doi.org/ 10.1029/2000TC900018

Jolivet, L., Faccenna, C., Huet, B., Labrousse, L., Le Pourhiet, L., Lacombe, O., et al. (2012). Aegean tectonics: Strain localization, slab tearing and trench retreat. Tectonophysics, 597-598, 1-33. https://doi.org/10.1016/j.tecto.2012.06.011

Kent, E., Boulton, S. J., Stewart, I. S., Whittaker, A. C., \& Alçiçek, M. C. (2016). Geomorphic and geologic constraints on the active norma faulting of the Gediz (Alaşehir) Graben, Western Turkey. Journal of the Geological Society, London, 173(4), 666-678. https://doi.org/ 10.1144 /jgs $2015-121$

Kent, E., Boulton, S. J., Whittaker, A. C., Stewart, I. S., \& Alçiçek, M. C. (2017). Normal fault growth and linkage in the Gediz (Alaşehir) Graben, Western Turkey, revealed by transient river long-profiles and slope-break knickpoints. Earth Surface Processes and Landforms, $42(5), 836-852$.

Koçyiğit, A., Yusufoğlu, H., \& Bozkurt, E. (1999). Evidence from the Gediz Graben for episodic two-stage extension in western Turkey. Journal of the Geological Society of London, 156(3), 605-616. https://doi.org/10.1144/gsigs.156.3.0605

Laurent, V., Beaudoin, A., Jolivet, L., Arbaret, L., Augier, R., Rabillard, A., \& Menant, A. (2015). Interrelations between extensional shear zones and synkinematic intrusions: The example of Ikaria Island (NE Cyclades, Greece). Tectonophysics, 651-652, 152-171.

Lips, A. L. W., Cassard, D., Sözbilir, H., Yilmaz, H., \& Wijbrans, J. R. (2001). Multistage exhumation of the Menderes Massif, western Anatolia (Turkey). International Journal of Earth Sciences, 89(4), 781-792. https://doi.org/10.1007/s005310000101

Lister, G. S., \& Baldwin, S. L. (1993). Plutonism and the origin of metamorphic core complexes. Geology, 21(7), 607-610. https://doi.org/ 10.1130/0091-7613(1993)021<0607:PATOOM>2.3.CO;2

Lister, G. S., Banga, G., \& Feenstra, A. (1984). Metamorphic core complexes of Cordilleran type in the Cyclades, Aegean Sea, Greece. Geology, 12(4), 221-225. https://doi.org/10.1130/0091-7613(1984)12<221:MCCOCT>2.0.CO;2 
Lister, G. S., \& Davis, G. A. (1989). The origin of metamorphic core complexes and detachment faults formed during Tertiary continental extension in the northern Colorado River region, U.S.A. Journal of Structural Geology, 11(1-2), 65-94. https://doi.org/10.1016/01918141(89)90036-9

McClaughry, J. D., \& Gaylord, D. R. (2005). Middle Eocene sedimentary and volcanic infilling of an evolving supradetachment basin: White Lake Basin, south-central British Columbia. Canadian Journal of Earth Sciences, 42(1), 49-66. https://doi.org/10.1139/ e04-105

Miller, E. L., Gans, P. B., \& Garing, J. (1983). The Snake Range décollement: An exhumed mid-Tertiary ductile-brittle transition. Tectonics, 2(3), 239-263. https://doi.org/10.1029/TC002i003p00239

Miller, K. G., Kominz, M. A., Browning, J. V., Wright, J. D., Mountain, G. S., Katz, M. E., et al. (2005). The Phanerozoic record of global sealevel change. Science, 310(5752), 1293-1298. https://doi.org/10.1126/science.1116412

Mücke, A. (1994). Postdiagenetic ferruginization of sedimentary rocks (sandstones, oolitic ironstones, kaolins and bauxites)—Including a comparative study of the reddening of red beds. In K. H. Wolf, \& G. V. Chilingarian (Eds.), Diagenesis, IV. Developments in sedimentology 5 1, (pp. 361-395). Amsterdam: Elsevier.

Oberhänsli, R., Candan, O., \& Wilke, F. (2010). Geochronological evidence of Pan-African eclogites from the central Menderes Massif, Turkey. Turkish Journal of Earth Sciences, 19, 431-447.

Öner, Z., \& Dilek, Y. (2011). Supradetachment basin evolution during continental extension: The Aegean province of western Anatolia, Turkey. Geological Society of America Bulletin, 123(11-12), 2115-2141. https://doi.org/10.1130/B30468.1

Osmundsen, P. T., \& Andersen, T. B. (2001). The middle Devonian basins of western Norway: Sedimentary response to large-scale transtensional tectonics? Tectonophysics, 332(1-2), 51-68. https://doi.org/10.1016/S0040-1951(00)00249-3

Platt, J. P., Behr, W. M., \& Cooper, F. J. (2015). Metamorphic core complexes: Windows into the mechanics and rheology of the crust. Journal of the Geological Society of London, 172(1), 9-27. https://doi.org/10.1144/jgs2014-036

Purvis, M., \& Robertson, A. (2005a). Sedimentation of the Neogene-recent Alaşehir (Gediz) continental graben system used to test alternative tectonic models for western (Aegean) Turkey. Sedimentary Geology, 173(1-4), 373-408. https://doi.org/10.1016/j. sedgeo.2003.08.005

Purvis, M., \& Robertson, A. (2005b). Miocene sedimentary evolution of the NE-SWtrending Selendi and Gördes basins, W Turkey: Implications for extensional processes. Sedimentary Geology, 174(1-2), 31-62. https://doi.org/10.1016/j.sedgeo.2004.11.002

Purvis, M., \& Robertson, A. H. F. (2004). A pulsed extension model for the Neogene-recent E-W-trending Alaşehir Graben and the NE-SW-trending Selendi and Gördes basins, western Turkey. Tectonophysics, 391(1-4), 171-201. https://doi.org/10.1016/j. tecto.2004.07.011

Ring, U. (2001). Stacking of nappes with different pressure-temperature paths: An example from the Menderes nappes of western Turkey. American Journal of Science, 301(10), 912-944. https://doi.org/10.2475/ajs.301.10.912

Ring, U., Brandon, M. T., Willett, S. D., \& Lister, G. S. (1999). Exhumation processes. Geological Society, London, Special Publications, 154(1), 1-27. https://doi.org/10.1144/GSL.SP.1999.154.01.01

Ring, U., \& Collins, A. S. (2005). U-Pb SIMS dating of synkinematic granites: Timing of core-complex formation in the northern Anatolide belt of western Turkey. Journal of the Geological Society, 162(2), 289-298. https://doi.org/10.1144/0016-764904-016

Ring, U., Gessner, K., Gungor, T., \& Passchier, C. W. (1999). The Menderes Massif of western Turkey and the Cycladic Massif in the Aegean —Do they really correlate? Journal of the Geological Society, 156(1), 3-6. https://doi.org/10.1144/gsjgs.156.1.0003

Ring, U., Johnson, C., Hetzel, R., \& Gessner, K. (2003). Tectonic denudation of a Late CretaceousTertiary collisional belt: Regionally symmetric cooling patterns and their relation to extensional faults in the Anatolide belt of western Turkey. Geological Magazine, 140(4), 421-441. https://doi.org/10.1017/S0016756803007878

Ritts, B. D., Berry, A. K., Johnson, C. L., Darby, B. J., \& Davis, G. A. (2010). Early Cretaceous supradetachment basins in the Hohhot metamorphic core complex, Inner Mongolia, China. Basin Research, 22(1), 45-60. https://doi.org/10.1111/j.1365-2117.2009.00433.x

Rossetti, F., Asti, R., Faccenna, C., Gerdes, A., Lucci, F., \& Theye, T. (2017). Magmatism and crustal extension: Constraining activation of the ductile shearing along the Gediz detachment, Menderes Massif (western Turkey). Lithos, 282-283, 145-162.

Sarıca, N. (2000). The Plio-Pleistocene age of Büyük Menderes and Gediz grabens and their tectonic significance on N-S extensional tec tonics in West Anatolia: Mammalian evidence from the continental deposits. Geological Journal, 35(1), 1-24. https://doi.org/10.1002/ (SICI)1099-1034(200001/03)35:1<1::AID-GJ834>3.0.CO;2-A

Sarikaya, M. A. (2004). Gediz ayrılma zonu: Fay kayacı stratigrafisi ve tektonik önemi (Gediz detachment zone: Fault rock stratigraphy and tectonic significance). Yerbilimleri Dergisi, 25, 63-79.

Şengör, A. M. C. (1987). Cross faults and differential stretching of hanging walls in regions of low-angle normal faulting: Examples from Western Turkey. In M. P. Coward, J. F. Dewey, \& P. L. Hancock (Eds.), Continental extensional tectonics, (pp. 575-589).

Şengör, A. M. C., \& Bozkurt, E. (2013). Layer-parallel shortening and related structures in zones undergoing active regional horizontal extension. International Journal of Earth Sciences, 102(1), 101-119. https://doi.org/10.1007/s00531-012-0777-0

Sengör, A. M. C., Satir, M., \& Akkök, R. (1984). Timing of tectonic events in the Menderes Massif, western Turkey: Implications for tectonic evolution and evidence for pan-African basement in Turkey. Tectonics, 3(7), 693-707. https://doi.org/10.1029/TC003i007p00693

Şengör, A. M. C., \& Yilmaz, Y. (1981). Tethyan evolution of Turkey: A plate tectonic approach. Tectonophysics, 75(3-4), 181-241. https://doi. org/10.1016/0040-1951(81)90275-4

Séranne, M., \& Séguret, M. (1987). The Devonian Basins of western Norway: Tectonics and kinematics of an extending crust. Geological Society of London, Special Publication, 28, 37-48.

Seward, D., Vanderhaeghe, O., Siebenaller, L., Thomson, S., Hibsch, C., Zingg, A., et al. (2009). Cenozoic tectonic evolution of Naxos Island through a multi-faceted approach of fission track analysis. Geological Society - Special Publications, 321(1), 179-196. https://doi.org/ $10.1144 /$ SP321.9

Seyitoğlu, G., Çemen, İ., \& Tekeli, O. (2000). Extensional folding in the Alaşehir Gediz graben, western Turkey. Journal of the Geological Society of London, 157(6), 1097-1100. https://doi.org/10.1144/jgs.157.6.1097

Seyitoğlu, G., Işık, V., \& Çemen, İ. (2004). Complete Tertiary exhumation history of the Menderes Massif, western Turkey: An alternative working hypothesis. Terra Nova, 16(6), 358-364. https://doi.org/10.1111/j.1365-3121.2004.00574.x

Seyitoğlu, G., Işık, V., \& Esat, K. (2015). A 3D model for the formation of turtleback surfaces: The Horzum Turtleback of western Turkey as a case study. Turkish Journal of Earth Sciences, 23, 479-494.

Seyitoğlu, G., \& Scott, B. C. (1992). The age of the Büyük Menderes graben (west Turkey) and its tectonic implications. Geological Magazine, 129, 239-242.

Seyitoğlu, G., Tekeli, O., Çemen, İ., Şen, Ş., \& Işık, V. (2002). The role of flexural rotation/rolling hinge model in the tectonic evolution of the Alaşehir Graben, western Turkey. Geological Magazine, 139, 15-26. 
Sissingh, W. (1972). Late Cenozoic Ostracoda of the South Aegean island arc (Vol. 6, p. 188). Utrecht, Netherlands: Utrecht Micropaleontological Bulletins.

Snyder, N. P., \& Hodges, K. V. (2000). Depositional and tectonic evolution of a supradetachment basin: ${ }^{40} \mathrm{Ar} /{ }^{39} \mathrm{Ar}$ geochronology of the Nova Formation, Panamint Range, California. Basin Research, 12(1), 19-30. https://doi.org/10.1046/j.1365-2117.2000.00108.x

Thomson, S. N., \& Ring, U. (2006). Thermochronologic evaluation of post-collision extension in the Anatolide Orogen, western Turkey. Tectonics, 25, TC3005. https://doi.org/10.1029/2005TC001833

Tinn, O., \& Meidla, T. (1999). Ordovician ostracodes from the Komstad Limestone. Bulletin of the Geological Society of Denmark, 46, 25-30. van Hinsbergen, D. J. J. (2011). A key extensional metamorphic complex reviewed and restored: The Menderes Massif of western Turkey Earth-Science Reviews, 102, 60-76.

van Houten, F. B. (1973). Origin of red beds: A review-1961-1972. Annual Review of Earth and Planetary Sciences, 1(1), 39-61. https://doi. org/10.1146/annurev.ea.01.050173.000351

Vetti, V. V., \& Fossen, H. (2012). Origin of contrasting Devonian supradetachment basin types in the Scandinavian Caledonides. Geology, 40(6), 571-574. https://doi.org/10.1130/G32512.1

Walker, T. R. (1967). Formation of red beds in modern and ancient deserts. Geological Society of America Bulletin, 78(3), $353-368$. https://doi.org/10.1130/0016-7606(1967)78[353:FORBIM]2.0.CO;2

Wang, X., Zheng, Y., \& Jia, W. (2004). Extension of the Louzidian metamorphic core complex and development of supradetachment basins in Southern Chifeng, Inner Mongolia, China. Acta Geologica Sinica, 78(1), 237-245.

Wernicke, B. (1985). Uniform-sense normal simple shear of the continental lithosphere. Canadian Journal of Earth Sciences, 22(1), 108-125. https://doi.org/10.1139/e85-009

Whitney, D. L., Teyssier, C., Rey, P., \& Buck, W. R. (2013). Continental and oceanic core complexes. Geological Society of America Bulletin 125(3-4), 273-298. https://doi.org/10.1130/B30754.1

Yılmaz, M., \& Gelişli, K. (2003). Stratigraphic-structural interpretation and hydrocarbon potential of the Alaşehir Graben, Western Turkey. Petroleum Geoscience, 9(3), 277-282. https://doi.org/10.1144/1354-079302-539

Yılmaz, Y., Genç, S. C., Gürer, Ö. F., Bozcu, M., Yılmaz, K., Karacık, Z., et al. (2000). When did the western Anatolian grabens begin to develop? Geological Society, London, Special Publications, 173(1), 353-384. https://doi.org/10.1144/GSL.SP.2000.173.01.17

Zachariasse, W. J., van Hinsbergen, D. J. J., \& Fortuin, A. R. (2011). Formation and fragmentation of a late Miocene supradetachment basin in central Crete: Implications for exhumation mechanisms of high-pressure rocks in the Aegean forearc. Basin Research, 23(6), 678-701. https://doi.org/10.1111/j.1365-2117.2011.00507.x 